\title{
Contribution of OxyR Towards Differential Sensitivity to Antioxidants in Xanthomonas oryzae pathovars oryzae and oryzicola
}

\author{
Xiayan Pan, Jian Wu, Shu Xu, Tingting Duan, Yabing Duan, Jianxin Wang, Feng Zhang, ${ }^{\dagger}$ and \\ Mingguo Zhou ${ }^{\dagger}$ \\ College of Plant Protection, State \& Local Joint Engineering Research Center of Green Pesticide Invention and Application, \\ Nanjing Agricultural University, Nanjing, 210095, China.
}

Accepted 12 June 2018.

\begin{abstract}
OxyR and SoxR are two transcriptional regulators in response to oxidative stress in most bacteria, and SoxR has been reported to be activated by the endogenous redox-cycling compound phenazine in phenazine-producing organisms. However, which transcriptional regulator is activated in pathogens treated with the antibiotic phenazine-1-carboxylic acid (PCA) has not been determined. In this study, we found that PCA treatment activated OxyR rather than SoxR in the phytopathogenic bacteria Xanthomonas oryzae pv. oryzae and $X$. oryzae pv. oryzicola. We also found that $X$. oryzae pv. oryzae was much more sensitive to PCA and $\mathrm{H}_{2} \mathrm{O}_{2}$ and had a defective antioxidant system (i.e., less of total antioxidant capacity and total catalase activity than $X$. oryzae pv. oryzicola, although $X$. oryzae pvs. oryzae and oryzicola are very closely related). Based on KEGG sequences, OxyR differs in 10 amino acids in $X$. oryzae pv. oryzae versus $X$. oryzae pv. oryzicola. By exchanging OxyR between $X$. oryzae pvs. oryzae and oryzicola, we elucidated that OxyR contributed to the differences in antioxidant capacity, total catalase activity, and sensitivity to PCA and $\mathrm{H}_{2} \mathrm{O}_{2}$. We also found that OxyR affected $X$. oryzae pvs. oryzae and oryzicola growth in a nutrient-poor medium, virulence on host plants (rice), and the hypersensitive response on nonhost plants (Nicotiana benthamiana). Thus, OxyR is a critical regulator that relates to the differences in antioxidative stress between $X$. oryzae pvs. oryzae and oryzicola and contributes to the differences in survival of them against oxidative stress.
\end{abstract}

Xanthomonas oryzae pv. oryzae (the causal agent of rice bacterial leaf blight) and $X$. oryzae pv. oryzicola (the causal agent of rice bacterial leaf streak) are two gram-negative phytopathogenic bacteria (Swings et al. 1990). Similar to many other plant pathogens, $X$. oryzae pvs. oryzae and oryzicola must overcome oxidative stress induced by oxidants in the environments or generated by plant cells during infection

${ }^{\dagger}$ Corresponding authors: Mingguo Zhou; E-mail: mgzhou@njau.edu.cn and Feng Zhang; E-mail: fengz@njau.edu.cn

Funding: This research was supported by the Key Program of National Natural Science Foundation of China (31730072) and the Fundamental Research Funds for the Central Universities (KYTZ201604).

*The $\boldsymbol{e}$-Xtra logo stands for "electronic extra" and indicates that three supplementary figures and three supplementary tables are published online.

(C) 2018 The American Phytopathological Society
(Aznar et al. 2015; Breitenbach et al. 2015; Fones and Preston 2012). Phenazine-1-carboxylic acid (PCA), a secondary metabolite secreted by Pseudomonas spp. and several plantassociated bacteria (Pectobacterium, Streptomyces, Burkholderia, Brevibacterium, and others) (Jaaffar et al. 2017; Morales et al. 2010; Saleh et al. 2009; Thomashow et al. 1990 ), is found to be effective against $X$. oryzae pvs. oryzae and oryzicola by stimulating the formation of reactive oxygen species (ROS) in cells in the presence of oxygen (Pan et al. 2017; Wang and Newman 2008; Xu et al. 2015). ROS such as hydrogen peroxide $\left(\mathrm{H}_{2} \mathrm{O}_{2}\right)$, the superoxide anion radical $\left(\mathrm{O}_{2}^{\bullet-}\right)$, and the hydroxyl radical ( $\mathrm{OH} \cdot)$ (Imlay 2015a,b) can damage nucleic acids, proteins, and lipids, ultimately resulting in cell death (Cabiscol et al. 2000). In order to avoid ROS-induced damage, bacteria have evolved several defense mechanisms. In prokaryotes, the primary defense mechanism involves scavenging enzymes systems, including catalase (CAT), alkyl hydroperoxide reductase (Ahp) subunits CF (AhpCF), and thioredoxin (Trx), which scavenge $\mathrm{H}_{2} \mathrm{O}_{2}$; and superoxide dismutase (SOD), which scavenges $\mathrm{O}_{2}^{\circ-}$ (Cooke et al. 2003; Vázquez-Torres 2012; Xia et al. 2017).

Two key transcriptional regulators, SoxR and OxyR, have been well known to regulate the enzymes in the antioxidant systems in response to oxidative stress (Sporer et al. 2017; Storz et al. 1990). SoxR is activated in response to $\mathrm{O}_{2}^{\bullet-}$ and, in turn, includes the transcription of target genes, including SOD (Pomposiello and Demple 2001; Seo et al. 2015; Singh et al. 2013). In contrast, OxyR is activated in response to $\mathrm{H}_{2} \mathrm{O}_{2}$ and, in turn, activates CAT, Trx, and AhpCF (Imlay 2015b; Seo et al. 2015). In phenazine-producing organisms, SoxR and OxyR have been researched widely. It is reported that SoxR can be directly activated by phenazines in Pseudomonas aeruginosa (Dietrich et al. 2008). PCA can alter the transcript levels of an efflux pump gene through SoxR in P. aeruginosa M18 (Du et al. 2015). OxyR is also important for defense against oxidative stress in P. aeruginosa (Vinckx et al. 2010). However, there have been few reports concerning the responses of SoxR or OxyR in phytopathogenic bacteria $X$. oryzae pvs. oryzae and oryzicola against PCA.

As two pathovars of $X$. oryzae, oryzae and oryzicola are very similar in the size of genome and gene content (Seo et al. 2008), and showed almost similar sensitivity to streptomycin (Xu et al. 2010). However, $X$. oryzae pv. oryzae is found to be much more sensitive than $X$. oryzae pv. oryzicola to PCA (Xu et al. 2015). This may be caused by different CAT activities in both bacteria as noted in our previous study (Pan et al. 2017; Xu et al. 2015) but the detailed mechanism needs to be exposed. Interestingly, 
CAT is regulated by OxyR in most bacteria, including $X$. oryzae pv. oryzae (Heo et al. 2009; Kong et al. 2004; Seo et al. 2015; Tseng et al. 2003; Yu et al. 2016), which raises the possibility that OxyR in phytopathogenic bacteria $X$. oryzae pvs. oryzae and oryzicola may be involved in regulating the enzymes in the antioxidant systems in response to PCA.

In this study, we deleted and exchanged the gene $\operatorname{oxy} R$, which encodes the transcriptional regulator OxyR in $X$. oryzae pvs. oryzae and oryzicola, and investigated the roles of OxyR in these two bacteria in response to PCA. We also revealed the differences in OxyR involved in the differences of the two bacteria in antioxidant capacity, total CAT activity, and sensitivity to $\mathrm{H}_{2} \mathrm{O}_{2}$. These results should help us shed light on the different oxidative stress response in $X$. oryzae pvs. oryzae and oryzicola and contribute to understanding the roles of OxyR in physiology and pathogenesis in these two bacteria.

\section{RESULTS}

Sensitivity of $X$. oryzae pvs. oryzae and oryzicola to phenazines, bismerthiazol, captan, and streptomycin on $X$. oryzae pvs. oryzae and oryzicola.

In the sensitivity tests, we found that $X$. oryzae pv. oryzicola was much less sensitive than $X$. oryzae pv. oryzae to the phenazines PCA, phenazine (PHZ), and 1-hydroxyphezine (1-OHPHZ) (Table 1). However, X. oryzae pvs. oryzae and oryzicola did not differ in sensitivity to bismerthiazol or captan and differed only to a small (but statistically significant, $P<0.05$ ) degree in sensitivity to the antibiotic streptomycin (Table 1). The concentration of PCA that resulted in $50 \%$ inhibition of bacterial cell growth $\left(\mathrm{EC}_{50}\right)$ values of bismerthiazol against $X$. oryzae pvs. oryzae and oryzicola were $12.83 \pm 1.34$ and $16.27 \pm$ $1.06 \mu \mathrm{g} / \mathrm{ml}$, respectively, and those of captan were $0.063 \pm$ 0.0169 and $0.091 \pm 0.0092 \mu \mathrm{g} / \mathrm{ml}$, respectively.

PCA activates OxyR and induces gene expression of CAT, Trx, and AhpCF in X. oryzae pvs. oryzae and oryzicola.

In an earlier study, PCA was found to activate SoxR in phenazine-producing pathogens but induced the gene expression of CAT (catB and katE) in X. oryzae pvs. oryzae and oryzicola with PCA treatment (Du et al. 2015; Pan et al. 2017). RNA sequencing (RNA-seq) also showed that the transcript levels of $\operatorname{oxy} R$, ankB (encoding AnkB, which interacts with CatB), catB (encoding CAT CatB), katE (encoding CAT KatE), $\operatorname{tr} x A$ (encoding $\operatorname{Trx}$ ), and $a h p C$ (encoding AhpC) were all upregulated in $X$. oryzae pv. oryzae ZJ173 with PCA treatment (Table 2). To further determine which transcriptional regulator was activated by PCA, and to determine whether the genes encoding other antioxidant enzymes were also induced by PCA in these two bacteria, quantitative reverse-transcription polymerase chain reaction (qRT-PCR) was performed. In the presence of PCA, the expression of $o x y R, \operatorname{ankB}, \operatorname{cat} B, \operatorname{trx} A, \operatorname{ahp} C$, and $a h p F$ (encoding $\mathrm{AhpF}$ ) increased in $X$. oryzae pv. oryzae $\mathrm{ZJ} 173$ (Fig. 1A). In contrast, the gene expression of oxyR, ankB, and $c a t B$ was not induced or slightly induced in $X$. oryzae pv. oryzicola RS105 with the same PCA treatment (Fig. 1B). Interestingly, higher concentrations of PCA induced the expression of ankB, catB, katE, and $\operatorname{tr} x A$ in RS105, and the highest test concentration induced the expression of $o x y R$ (Fig. 1C). In $X$. oryzae $\mathrm{pv}$. oryzae, PCA only induced the expression of sodM1. In $X$. oryzae pv. oryzicola, PCA did not induce the expression of soxR or the genes encoding SOD.

\section{The antioxidant abilities}

of $X$. oryzae pvs. oryzae and oryzicola.

RNA-seq data indicated that the transcript levels of oxyR and the genes $(a n k B, c a t B, k a t E$, and $a h p C)$ in the antioxidant system regulated by OxyR were higher in $X$. oryzae pv. oryzicola than in $X$. oryzae pv. oryzae (Table 2). Thus, we suspected that antioxidant ability is much stronger in $X$. oryzae pv. oryzicola than in $X$. oryzae pv. oryzae. To test this, we compared $\mathrm{H}_{2} \mathrm{O}_{2}$ sensitivity, total antioxidant capacity, and CAT activity. The results indicated that $X$. oryzae pv. oryzae was more sensitive to $\mathrm{H}_{2} \mathrm{O}_{2}$ than $X$. oryzae pv. oryzicola (Fig. 2A). Similarly, total antioxidant capacity and CAT activity were greater in $X$. oryzae pv. oryzicola than that in X. oryzae pv. oryzae (Fig. $2 \mathrm{D}$ and $\mathrm{E})$.

\section{Sequence analysis, deletion, replacement, and} complementation of $o x y R$

in $X$. oryzae pvs. oryzae and oryzicola.

Consistent with the finding that CAT, Trx, and Ahp are regulated by OxyR (Seo et al. 2015), the transcript levels of these genes were much higher in $X$. oryzae pv. oryzicola than in $X$. oryzae pv. oryzae according to RNA-seq (Table 2). We then aligned amino acids encoded by oxy $R$ in $X$. oryzae pvs. oryzae and oryzicola and found 10 different sites (Supplementary Fig. S1). To further investigate whether the differences in amino acids may contribute to the differences in antioxidant ability, $\mathrm{H}_{2} \mathrm{O}_{2}$ sensitivity, and $\mathrm{PHZ}$ sensitivity, we generated oxy $R$ gene deletion mutants, replacement mutants, and complementation mutants in $X$. oryzae pvs. oryzae and oryzicola. The oxyR deletion mutants for $X$. oryzae pv. oryzae ZJ173 and X. oryzae pv. oryzicola RS105, which were designated $\Delta \mathrm{Z}($ oxyR), and $\Delta \mathrm{R}$ $(o x y R)$, respectively; the wild-type $\mathrm{ZJ} 173$ when the $\operatorname{oxy} R$ gene of ZJ173 was replaced with the $\operatorname{oxy} R$ gene of RS105, which was designated as ZJ173-oxy $R^{\mathrm{RS} 105}$; and the wild-type RS105 when the $\operatorname{oxyR}$ gene of RS105 was replaced with the $\operatorname{oxy} R$ gene of $\mathrm{ZJ} 173$, which was designated as RS105-oxy $R^{\mathrm{ZJ} 173}$, were confirmed by PCR amplification. The replacement mutants were also sequenced.

\section{Determination of gene expression}

in the antioxidant system, total antioxidant capacity, and CAT activity in oxy $R$ mutants.

qRT-PCR was used to assess the expression of genes in the antioxidant system in the oxyR mutants. The results indicated that the expression of $\operatorname{cat} B$, ankB, and $\operatorname{tr} x A$ was significantly decreased in the $\operatorname{oxy} R$ deletion mutants of both strains (Fig. 2B and C). The expression of genes encoding $\mathrm{AhpCF}(a h p C$ and $a h p F$ ) was greater in the deletion mutants than in the wild-type strains. The expression of the genes encoding CAT (katE) was greatly enhanced in $\Delta \mathrm{R}($ oxy $R)$ but was not changed in $\Delta \mathrm{Z}$ (oxyR) (Fig. 2B and C). Interestingly, the expression of all genes tested except $\operatorname{srp} A$ and $a h p F$ was

Table 1. Sensitivity of Xanthomonas oryzae pv. oryzae (ZJ173) and X. oryzae pv. oryzicola (RS105) to phenazines (phenazine-1-carboxylic acid [PCA], phenazine [PHZ], and 1-hydroxyphezine [1-OH-PHZ]), bismerthiazol, streptomycin, and captan

\begin{tabular}{|c|c|c|c|}
\hline \multirow[b]{2}{*}{ Pesticides } & \multicolumn{2}{|c|}{$\mathrm{EC}_{50}(\mu \mathrm{g} / \mathrm{ml})^{\mathrm{z}}$} & \multirow{2}{*}{$\begin{array}{c}\text { Ratio } \\
(\mathbf{R S 1 0 5 / Z J 1 7 3 )}\end{array}$} \\
\hline & ZJ173 & RS105 & \\
\hline PCA & $0.21 \pm 0.032 \mathrm{a}$ & $14.56 \pm 1.89 b$ & 69 \\
\hline PHZ & $0.0025 \pm 0.0011 \mathrm{a}$ & $2.31 \pm 0.78 b$ & 924 \\
\hline 1-OH-PHZ & $0.0062 \pm 0.0028 \mathrm{a}$ & $1.91 \pm 0.54 \mathrm{~b}$ & 308 \\
\hline Bismerthiazol & $12.83 \pm 1.34 \mathrm{a}$ & $16.27 \pm 1.06 \mathrm{a}$ & 1.27 \\
\hline Streptomycin & $0.48 \pm 0.15 \mathrm{a}$ & $1.76 \pm 0.33 b$ & 3.67 \\
\hline Captan & $0.063 \pm 0.0169 \mathrm{a}$ & $0.091 \pm 0.0092 \mathrm{a}$ & 1.44 \\
\hline
\end{tabular}

${ }^{\mathrm{z}} \mathrm{EC}_{50}=$ the concentration of PCA that resulted in $50 \%$ inhibition of bacterial cell growth. Values are means \pm standard error of three experiments. Means in a row with different letters are significantly different at $P<0.05$. 
significantly greater than in the wild-type $X$. oryzae $\mathrm{pv}$. oryzae $\mathrm{ZJ} 173$ when the oxyR gene of $\mathrm{ZJ} 173$ was replaced with the $o x y R$ gene of RS105 (ZJ173-oxyR ${ }^{\mathrm{RS} 105}$ ) (Fig. 2B). In contrast, the expression of $a n k B, c a t B, k a t E$, and $\operatorname{trx} A$ was significantly lower but the expression of $\operatorname{ahpC}$ was significantly greater than in the wild-type strain RS105 when the $o x y R$ gene of RS105 was replaced with the oxyR gene of ZJ173 (RS105$o x y R^{\mathrm{ZJ} 173}$ ) (Fig. 2C).

We then measured the total antioxidant capacity and CAT activity in the $\operatorname{oxy} R$ mutants. The deletion of $\operatorname{oxy} R$ significantly reduced the total antioxidant capacity (Fig. 2D) and CAT activity (Fig. 2E) of both deletion mutants. When the oxyR gene of $X$. oryzae pv. oryzae ZJ173 was replaced with the oxyR gene of $X$. oryzae pv. oryzicola RS105 (ZJ173oxy $\left.R^{\mathrm{RS} 105}\right)$, total antioxidant capacity and CAT activity were significantly greater than in the wild type. In contrast, replacement of the $o x y R$ gene of RS105 with the $\operatorname{oxy} R$ gene of ZJ173 (RS105-oxyR $R^{\mathrm{ZJ1} / 3}$ ) did not restore the total antioxidant capacity and CAT activity to the levels in the wild-type RS105 (Fig. 2D and E).

\section{Sensitivities of OxyR mutants to $\mathrm{H}_{2} \mathrm{O}_{2}$ and PCA.}

The deletion mutants $\Delta \mathrm{Z}($ oxyR $)$ and $\Delta \mathrm{R}(o x y R)$ were more sensitive than their wild types $(X$. oryzae pv. oryzae $\mathrm{ZJ} 173$ and $X$. oryzae pv. oryzicola $\mathrm{RS} 105$, respectively) to $\mathrm{H}_{2} \mathrm{O}_{2}$ (Fig. 3A). The replacement mutant ZJ173-oxyR ${ }^{\mathrm{RS} 105}$ was more resistant than $\mathrm{ZJ} 173$ to $\mathrm{H}_{2} \mathrm{O}_{2}$, and the sensitivity to $0.1 \mathrm{mM} \mathrm{H}_{2} \mathrm{O}_{2}$ was similar for $\mathrm{ZJ} 173-o x y R^{\mathrm{RS} 105}$ and $\mathrm{RS} 105$. In contrast, the replacement mutant RS105-oxy $R^{\mathrm{ZJ} 173}$ was more sensitive than RS105 to $\mathrm{H}_{2} \mathrm{O}_{2}$, and its sensitivity to $0.05 \mathrm{mM} \mathrm{H}_{2} \mathrm{O}_{2}$ was intermediate between that of $\Delta \mathrm{R}($ oxyR) and $\mathrm{RS} 105$.

The deletion mutants $\Delta \mathrm{Z}($ oxy $R)$ and $\Delta \mathrm{R}($ oxy $R)$ were more sensitive than their wild types to PCA (Fig. 3B; Table 3). The replacement mutant RS105-oxy $R^{\mathrm{ZJ} 173}$ was also more sensitive to PCA than $X$. oryzae pv. oryzicola RS105. However, the sensitivity to PCA did not significantly differ between the replacement mutant $\mathrm{ZJ} 173-$ oxy $R^{\mathrm{RS} 105}$ and $X$. oryzae pv. oryzae ZJ173 (i.e., replacement of its $o x y R$ gene with that from RS105 did not increase its resistance to PCA).

\section{OxyR affects ROS accumulation in $X$. oryzae pvs. oryzae and oryzicola in response to PCA.}

In our previous study, PCA treatment significantly increased ROS levels in $X$. oryzae pv. oryzae (Xu et al. 2015). To further investigate whether ROS scavenging ability in $X$. oryzae pvs. oryzae and oryzicola is related to OxyR, we quantified ROS accumulation in the $\operatorname{oxy} R$ mutants after treatment with PCA. In

Table 2. Genes upregulated or downregulated in both Xanthomonas oryzae pv. oryzae (ZJ173) treated with phenazine-1-carboxylic acid (PCA) at $4 \mu \mathrm{g} / \mathrm{ml}$ and $X$. oryzae pv. oryzicola (RS105) relative to $X$. oryzae pv. oryzae $\mathrm{ZJ} 173^{\mathrm{z}}$

\begin{tabular}{|c|c|c|c|c|}
\hline Gene ID & Gene name & $\begin{array}{c}\text { Fold change } \\
\text { (ZJ173 PCA vs. ZJ173) }\end{array}$ & $\begin{array}{c}\text { Fold change } \\
(\text { RS105 vs. ZJ173) }\end{array}$ & Annotation \\
\hline YP_198679.1 & $\operatorname{trx} A$ & 13.96 & NA & Thioredoxin \\
\hline YP_199041.6 & hemB & 3.29 & 2.06 & $\Delta$-Aminolevulinic acid dehydratase \\
\hline YP_199056.1 & $c a t B$ & 11.13 & 21.04 & Catalase \\
\hline YP_199057.1 & ankB & 18.76 & 27.23 & Ankyrin-like protein \\
\hline YP_199106.1 & $z w f$ & 2.28 & 2.23 & Glucose-6-phosphate 1-dehydrogenase \\
\hline YP_199125.1 & pcaC & 2.34 & 2.38 & 4-Carboxymuconolactone decarboxylase \\
\hline YP_199278.1 & $\operatorname{cioA}$ & 2.84 & 10.29 & Cyanide insensitive terminal oxidase \\
\hline YP_199326.1 & $\operatorname{mot} B$ & 2.59 & 9.79 & Flagellar motor protein \\
\hline YP_199499.1 & Рпис & 2.84 & 4.08 & Nicotinamide mononucleotide transporter \\
\hline YP_199617.1 & $\operatorname{cirA}$ & 0.47 & 0.11 & Colicin I receptor \\
\hline YP_199994.1 & іисA & 0.43 & 0.20 & Iron transporter \\
\hline YP_200043.1 & $y n h D$ & 0.38 & 0.48 & $\mathrm{ABC}$ transporter ATP-binding protein \\
\hline YP_200045.1 & $\ldots$ & 0.32 & 0.43 & Predicted transcriptional regulator \\
\hline YP_200092.1 & $\operatorname{Vgr} G$ & 0.46 & 0.30 & VGR-related protein \\
\hline YP_200105.1 & cheR & 10.57 & 92.02 & Response regulator for chemotaxis \\
\hline YP_200106.1 & vieA & 4.78 & 58.37 & Response regulator \\
\hline YP_200108.1 & $m c p$ & 2.33 & 68.91 & Chemotaxis protein \\
\hline YP_200109.1 & cheA & 2.68 & 32.02 & Chemotaxis histidine protein kinase \\
\hline YP_200359.1 & $\ldots$ & 3.70 & 29.78 & Hypothetical protein \\
\hline YP_200386.1 & pilH & 0.46 & 0.45 & $\begin{array}{l}\text { Twitching motility two-component system response } \\
\text { regulator }\end{array}$ \\
\hline YP_200408.1 & bga & 0.25 & 0.25 & $\beta$-Galactosidase \\
\hline YP_200409.1 & $\ldots$ & 0.31 & 0.36 & Putative $\alpha$-1,2-mannosidase \\
\hline YP_200411.1 & EmrA & 0.37 & 0.0012 & multidrug resistance efflux pump \\
\hline YP_200413.1 & tfus2961 & 0.30 & 0.0012 & hypothetical protein \\
\hline YP_200422.1 & fucAl & 0.20 & 0.20 & $\alpha$-L-fucosidase \\
\hline YP_200423.1 & iroN & 0.25 & 0.25 & TonB-dependent receptor \\
\hline YP_200444.1 & BtuB & 0.50 & 0.47 & Outer membrane cobalamin receptor protein \\
\hline YP_200505.1 & $\ldots$ & 2.12 & 3.48 & Conserved hypothetical protein \\
\hline YP_200521.1 & $\ldots$ & 0.48 & 0.49 & Serine protease \\
\hline YP_200540.1 & araJ & 2.20 & 2.20 & MFS transporter \\
\hline YP_200541.1 & $\ldots$ & 18.51 & 2.12 & Conserved hypothetical protein \\
\hline YP_200597.1 & CcmA & 0.40 & 0.0014 & $\begin{array}{l}\text { ABC-type multidrug transport system, ATPase } \\
\text { component }\end{array}$ \\
\hline YP_200619.1 & fas $D$ & 2.15 & 2.60 & Outer membrane usher protein FasD \\
\hline YP_200711.1 & $\ldots$ & 0.35 & 0.43 & $\mathrm{~N}$-acyl-D-glucosamine 2-epimerase \\
\hline YP_200714.1 & UbiE & 2.36 & 2.72 & $\begin{array}{l}\text { Methylase involved in ubiquinone/menaquinone } \\
\text { biosynthesis }\end{array}$ \\
\hline YP_200991.6 & bglS & 0.41 & 0.27 & $\beta$-Glucosidase \\
\hline
\end{tabular}

\footnotetext{
${ }^{\mathrm{z}}$ Data shown in bold indicate the genes involved in the antioxidant system. NA = not available.
} 
response to PCA, ROS accumulation was greater in $o x y R$ deletion mutants $\Delta \mathrm{Z}($ oxyR $)$ and $\Delta \mathrm{R}($ oxyR) than in their respective wild types (Fig. 4). ROS accumulation was lower for ZJ173-oxy $R^{\mathrm{RS} 105}$ than for its wild type and was higher for RS105-oxyR $R^{\mathrm{ZJ} 173}$ than for its wild type (i.e., the exchange of $o x y R$ genes reduced ROS accumulation in $X$. oryzae pv. oryzae $\mathrm{ZJ} 173$ and increased ROS accumulation in $X$. oryzae pv. oryzicola RS105).

OxyR is required for growth and full virulence in a host (rice) and contributes to the hypersensitive response in a nonhost (Nicotiana benthamiana).

To determine whether OxyR is involved in growth, we measured the growth rate of the oxyR mutants in a minimal (MMX) medium and in a nutrient-rich (NB) medium. In MMX medium, $\Delta \mathrm{Z}($ oxyR) could not grow (Fig. 5A), while $\Delta \mathrm{R}($ oxyR) grew slowly (Fig. 5B). In MMX medium, ZJ173-oxy $R^{\mathrm{RS} 105}$ grew slightly faster than the wild-type strain $X$. oryzae pv. oryzae ZJ173 (Fig. 5A) but RS105-oxyR ${ }^{\mathrm{ZJ} 173}$ grew slower than the wildtype strain $X$. oryzae pv. oryzicola RS105 (Fig. 5B). The growth of both $\operatorname{oxy} R$ complementation mutants was similar to that of their respective wild types in MMX medium. In NB medium, the growth rate of $\Delta \mathrm{Z}(o x y R)$ was slightly slower than that of the wild-type strain ZJ173 (Fig. 5C), and the growth rates of $X$. oryzae pv. oryzicola oxyR mutants did not differ from that of the wild-type strain $X$. oryzae pv. oryzicola RS105.

The earliest observable responses to plant pathogens include an oxidative burst followed by the accumulation of ROS (Wojtaszek 1997). Because OxyR has been demonstrated to play a critical role in response to ROS which produced by the interaction of plant and bacterial pathogens (Ishiga and Ichinose 2016), we performed virulence, bacterial number, and hypersensitive response (HR) assays to determine whether OxyR is important in host and nonhost interactions. These assays included the mutants and wild types of $X$. oryzae pvs. oryzae and oryzicola and host rice plants and nonhost Nicotiana benthamiana plants. On rice, both deletion mutants $\Delta \mathrm{Z}($ oxyR $)$ and $\Delta \mathrm{R}($ oxyR) were less virulent than their respective wild types (Fig. 5D and E). The virulence on rice was greater for ZJ173oxy $R^{\mathrm{RS} 105}$ than for the wild-type strain (i.e., replacement of the oxy $R$ gene of $X$. oryzae pv. oryzae $\mathrm{ZJ} 173$ with the $\operatorname{oxy} R$ gene of $X$. oryzae pv. oryzicola RS105 resulted in a substantial increase in virulence) (Fig. 5D). In contrast, the virulence on rice was not restored in RS105-oxyR $R^{\mathrm{ZJ} 173}$ (Fig. 5E). At 1 day postinoculation (dpi) and $4 \mathrm{dpi}$, the bacterial numbers of $\Delta \mathrm{Z}($ oxy $R), \Delta \mathrm{R}($ oxy $R)$, and RS105-oxy $R^{\mathrm{ZJ173}}$ were significantly reduced compared with their respective wild-type strains. At $4 \mathrm{dpi}$, the bacterial numbers of $\mathrm{ZJ} 173-o x y R^{\mathrm{RS} 105}$ were significantly increased in comparison

Table 2. (Continued from previous page)

\begin{tabular}{|c|c|c|c|c|}
\hline Gene ID & Gene name & $\begin{array}{c}\text { Fold change } \\
\text { (ZJ173 PCA vs. ZJ173) }\end{array}$ & $\begin{array}{c}\text { Fold change } \\
\text { (RS105 vs. ZJ173) }\end{array}$ & Annotation \\
\hline YP_201207.1 & cheV & 6.53 & 73.85 & Chemotaxis protein \\
\hline YP_201250.1 & fliP & 0.46 & 0.45 & Flagellar biosynthetic protein \\
\hline YP_201251.1 & fliQ & 0.40 & 0.18 & Flagellar biosynthesis \\
\hline YP_201255.1 & $\ldots$ & 2.57 & 17.11 & GGDEF family protein (diguanylate cyclase) \\
\hline YP_201377.1 & $a c v B$ & 0.37 & 0.30 & Virulence protein \\
\hline YP_201413.1 & $g a b D$ & 2.36 & 2.07 & Succinate-semialdehyde dehydrogenase \\
\hline YP_201622.1 & $\ldots$ & 3.25 & 73.32 & $\begin{array}{l}\text { Mg-protoporphyrin IX monomethyl ester oxidative } \\
\text { cyclase }\end{array}$ \\
\hline YP_201632.1 & $R f b X$ & 3.60 & 7.07 & $\begin{array}{l}\text { Membrane protein involved in the export of O-antigen } \\
\text { and teichoic acid }\end{array}$ \\
\hline YP_201634.1 & $\ldots$ & 5.46 & 26.72 & Hypothetical protein \\
\hline YP_201639.1 & $\ldots$ & 5.82 & 32.72 & Cytochrome C \\
\hline YP_201648.1 & $\operatorname{cycK}$ & 2.81 & 17.10 & C-type cytochrome biogenesis membrane protein \\
\hline YP_201758.1 & btuB & 4.39 & 21.27 & Pseudogene \\
\hline YP_201776.1 & dapA & 2.45 & 2.41 & Dihydroxydipicolinate synthase \\
\hline YP_201777.1 & HcaD & 2.10 & 2.33 & Oxidoreductase \\
\hline YP_201959.1 & oar & 2.26 & 3.92 & Oar protein \\
\hline YP_202062.6 & katE & 6.71 & 2.51 & Catalase \\
\hline YP_202150.1 & $\ldots$ & 0.48 & 0.24 & Hypothetical protein \\
\hline YP_202284.1 & $\operatorname{ahpC}$ & 3.84 & 3.98 & Alkyl hydroperoxide reductase \\
\hline YP_202286.1 & oxyR & 2.39 & 7.03 & Oxidative stress transcriptional regulator \\
\hline YP_202298.1 & $\ldots$ & 0.40 & 0.15 & Two-component system regulatory protein \\
\hline YP_202435.1 & ppc & 2.67 & 3.31 & Phosphoenolpyruvate carboxylase \\
\hline YP_202449.1 & metF & 3.31 & 2.84 & 5,10-Methylenetetrahydrofolate reductase \\
\hline YP_202503.1 & $\ldots$ & 2.21 & 2.22 & Conserved hypothetical protein \\
\hline YP_202732.1 & $\ldots$ & 3.88 & 14.45 & Conserved hypothetical protein \\
\hline YP_202735.1 & $\ldots$ & 2.25 & 3.90 & Conserved hypothetical protein \\
\hline YP_202753.1 & yiaA & 0.44 & 0.025 & Membrane protein \\
\hline YP_202973.1 & $\ldots$ & 2.26 & 141.39 & Conserved hypothetical protein \\
\hline YP_203016.1 & $\operatorname{accC}$ & 0.30 & 0.13 & Biotin carboxylase \\
\hline YP_203017.1 & $a c c D$ & 0.32 & 0.12 & Acetyl-coenzyme A carboxylase carboxyl transferase \\
\hline YP_203056.6 & $x y l A$ & 0.28 & 0.21 & Xylose isomerase \\
\hline YP_203096.1 & $\ldots$ & 0.46 & 0.36 & Conserved hypothetical protein \\
\hline YP_203167.6 & $\ldots$ & 2.24 & 4.33 & Quinone oxidoreductase \\
\hline YP_203168.1 & mocA & 2.45 & 3.21 & Rhizopine catabolism protein mocA \\
\hline YP_203174.1 & $\ldots$ & 0.36 & 0.00090 & RTS $\beta$ protein (L-fuconate dehydratase) \\
\hline YP_203175.1 & $M h p D$ & 0.42 & 0.00073 & $\begin{array}{l}\text { 2-Keto-4-pentenoate hydratase/2-oxohepta-3-ene-1,7- } \\
\text { dioic acid hydratase (catechol pathway) }\end{array}$ \\
\hline YP_203176.1 & исрA & 0.46 & 0.0015 & Oxidoreductase \\
\hline YP_203178.1 & Tas & 0.37 & 0.0016 & Oxidoreductase \\
\hline
\end{tabular}


with the wild-type strain ZJ173 (Fig. 5F and G). In the HR assay, the HR was stronger for the deletion mutants $\Delta \mathrm{Z}($ oxy $R)$ and $\Delta \mathrm{R}$ $($ oxyR) than for their respective wild types (Fig. 5H). The HR in $N$. benthamiana was less for ZJ173-oxyR $R^{\mathrm{RS} 105}$ but greater for $\mathrm{RS} 105-o x y R^{\mathrm{ZJ} 173}$ relative to their respective wild types (Fig. $5 \mathrm{H}$ ).

\section{DISCUSSION}

As noted above, X. oryzae pv. oryzae and X. oryzae pv. oryzicola are important bacterial pathogens of rice (Lang et al.
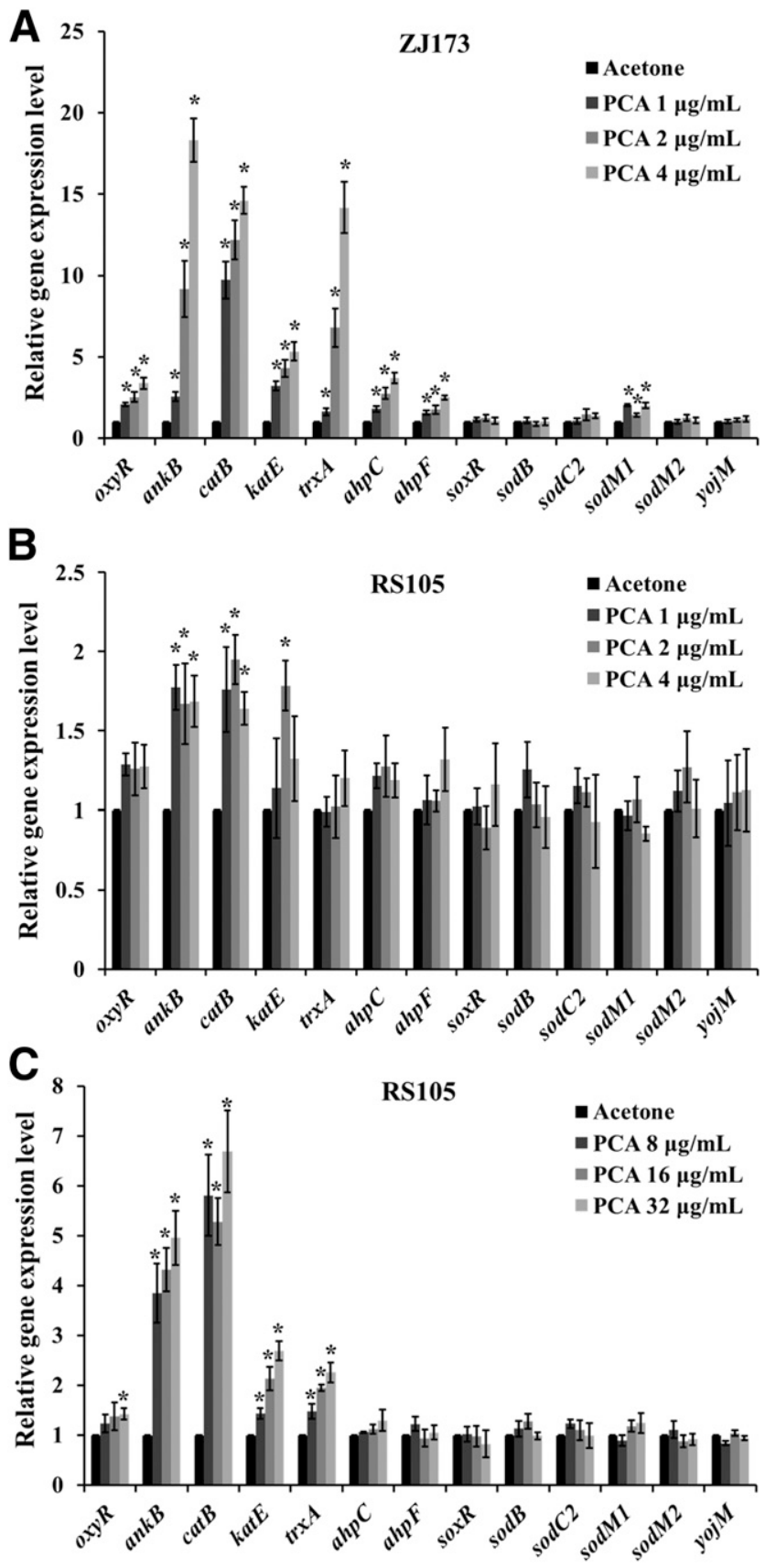

Fig. 1. Expression of $o x y R$, soxR and the genes involved in antioxidant systems in A, Xanthomonas oryzae pv. oryzae ZJ173 and B and C, X. oryzae pv. oryzicola strain RS105 in response to phenazine-1-carboxylic acid (PCA). Tested strains were grown in nutrient-rich medium to an optical density at $600 \mathrm{~nm}$ of 0.2 , and PCA was added to a final concentration of 1,2 , or $4 \mu \mathrm{g} / \mathrm{ml}$ for ZJ173 (A) and RS105 (B), and to a final concentration of 8, 16 , or $32 \mu \mathrm{g} / \mathrm{ml}$ for RS105 (C). The amount of RNA in acetone was used as the control and was set at 1.0. Values are means \pm standard deviation from three biological replicates and asterisks $(*)$ indicate $P$ value $<0.01$ ( $t$ test).
2010; Niño-Liu et al. 2006; Ou 1985). The two bacteria are very closely related (i.e., they not only infect the same host but also have genomes of similar size, gene content, and percent $\mathrm{G}+\mathrm{C}$ ) (Seo et al. 2008). In the current study, however, PCA and also PHZ and 1-PHZ-OH were much more effective against $X$. oryzae pv. oryzae than $X$. oryzae pv. oryzicola (Table 1 ). $X$. oryzae pvs. oryzae and oryzicola did not greatly differ in their sensitivity to other commonly used bactericides such as bismerthiazol and streptomycin and fungicide captan. The results indicated that the differences in sensitivity to phenazines in $X$. oryzae pvs. oryzae and oryzicola may be specific. It is still unclear why $X$. oryzae pv. oryzae has specific sensitivity to phenazines. In this study, we identified a transcriptional regulator, OxyR, in X. oryzae pvs. oryzae and oryzicola, that relates to the differences in total antioxidant capacity, CAT activity, and sensitivity to $\mathrm{H}_{2} \mathrm{O}_{2}$. Moreover, our study also revealed that OxyR affects the sensitivity to PCA and participates in the pathogenicity of $X$. oryzae pvs. oryzae and oryzicola on host rice and HR on nonhost $N$. benthamiana.

PCA is well known as a redox-active compound that affects the endogenous redox balance in phenazine-producing organisms and in non-phenazine-producing pathogens; the change in redox balance resulting from PCA treatment causes the target pathogens to produce ROS, which can result in cell death (Okegbe et al. 2017; Xu et al. 2015). Unlike endogenous pyocyanin, which activates SoxR in a phenazine-producing strain of $P$. aeruginosa (Dietrich et al. 2008), PCA treatment did not activate SoxR in $X$. oryzae pvs. oryzae and oryzicola but activated OxyR and the genes typically involved in detoxification of $\mathrm{H}_{2} \mathrm{O}_{2}$ in both bacteria in the current study (Fig. 1; Table 2). ROS accumulates in $X$. oryzae pv. oryzae treated with PCA (Xu et al. 2015), and levels of ROS accumulation in the current study were higher in $X$. oryzae pv. oryzae than in $X$. oryzae pv. oryzicola (Fig. 4). In addition, RNA-seq indicated that transcript levels of the relevant genes were higher in $X$. oryzae pv. oryzicola than in $X$. oryzae pv. oryzae (Table 2). These results suggested that antioxidant ability may be much weaker in $X$. oryzae pv. oryzae than in $X$. oryzae pv. oryzicola. In support of this inference, we found that $X$. oryzae pv. oryzae was more sensitive than $X$. oryzae pv. oryzicola to exogenous $\mathrm{H}_{2} \mathrm{O}_{2}$ (Fig. $2 \mathrm{~A})$, and that total antioxidant capacity and CAT activity were lower in $X$. oryzae pv. oryzae than in $X$. oryzae pv. oryzicola (Fig. 2D and E). The current results further provide strong evidence that the ROS scavenging machinery is much less effective in $X$. oryzae pv. oryzae than in X. oryzae pv. oryzicola, such that $X$. oryzae pv. oryzae is much more sensitive to $\mathrm{H}_{2} \mathrm{O}_{2}$ and other redox compounds than $X$. oryzae pv. oryzicola.

OxyR is widely distributed in bacteria and is directly oxidized by $\mathrm{H}_{2} \mathrm{O}_{2}$; once oxidized, it binds to DNA and thereby regulates gene expression so as to reduce $\mathrm{H}_{2} \mathrm{O}_{2}$ levels (Aslund et al. 1999; Choi et al. 2001; Ieva et al. 2008; Loprasert et al. 2000). In the current study, the genes induced in X. oryzae pv. oryzae by PCA are also regulated by OxyR (Liu et al. 2016; $\mathrm{Yu}$ et al. 2016). Based on KEGG sequences, OxyR in $X$. oryzae pvs. oryzae and oryzicola differs in 10 amino acids. Given these results and the differences in antioxidant system and CAT activity, we suspected that OxyR might be involved in regulating the expression of enzymes in the antioxidant system in response to PCA, and that this regulation may reduce sensitivity to PCA and may be a possible cause of the difference in the antioxidant systems of $X$. oryzae pv. oryzae versus $X$. oryzae pv. oryzicola. As expected, the expression was significantly decreased for $a n k B, \operatorname{cat} B$, and $\operatorname{tr} x A$ but was increased for $a h p C$ and $a h p F$ in the $o x y R$ deletion mutants of both $X$. oryzae pvs. oryzae and oryzicola. In addition, the expression of $o x y R, a n k B, \operatorname{catB}$, katE, $\operatorname{tr} x A$, and $a h p C$ was significantly increased when replacing the oxy $R$ gene in 
$X$. oryzae pv. oryzae ZJ173 with the oxyR gene from $X$. oryzae pv. oryzicola RS105 (Fig. 2B). The changes of the gene expression were further demonstrated to influence the total antioxidant capacity in the oxyR mutants (Fig. 2B and C). Combined with our previous report that CatB is the major CAT in $X$. oryzae pvs. oryzae and oryzicola and helps protect $X$. oryzae pvs. oryzae and oryzicola under $\mathrm{H}_{2} \mathrm{O}_{2}$ and PCA stresses (Pan et al. 2017), the current results show that CAT activity was dramatically reduced when we deleted $o x y R$ but was significantly increased in ZJ173-oxy $R^{\mathrm{RS} 105}$, when the $o x y R$ gene in $X$. oryzae pv. oryzae was replaced with the $o x y R$ gene from RS105. In contrast, replacement of the oxy $R$ gene in $X$. oryzae pv. oryzicola with the $o x y R$ gene from $X$. oryzae pv. oryzae ZJ173 did not restore the total antioxidant capacity and CAT activity to the levels of the wild-type strain RS105. These results indicated that differences in OxyR between $X$. oryzae pvs. oryzae and oryzicola contribute to the differences in the antioxidant abilities of $X$. oryzae pv. oryzae versus $X$. oryzae pv. oryzicola.

Sensitivity of ZJ173-oxy $R^{\mathrm{RS} 105}$ to exogenous $\mathrm{H}_{2} \mathrm{O}_{2}$ was substantially reduced compared with the wild-type strain $X$. oryzae pv. oryzae ZJ173, and was close to the wild-type strain $X$. oryzae
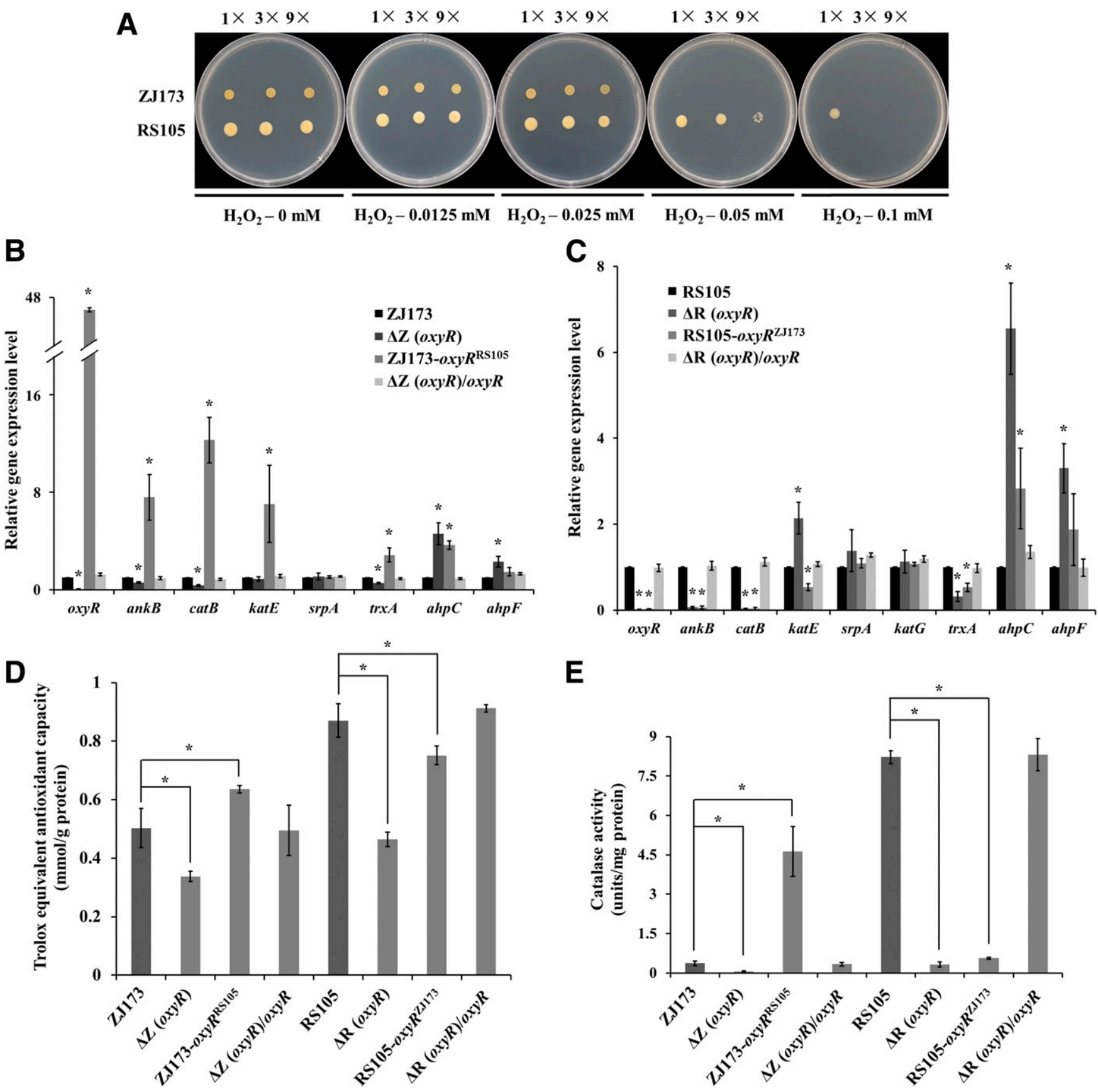

Fig. 2. A, $\mathrm{H}_{2} \mathrm{O}_{2}$ sensitivity of Xanthomonas oryzae pv. oryzae ZJ173 and X. oryzae pv. oryzicola RS105. Gene expression of oxyR and genes regulated by it involved in antioxidant systems in $\mathbf{B}, X$. oryzae pv. oryzae strains and $\mathbf{C}, X$. oryzae pv. oryzicola strains; $\mathbf{D}$, total antioxidant capacity; and $\mathbf{E}$, total catalase activity of $X$. oryzae pv. oryzae (ZJ173), X. oryzae pv. oryzicola (RS105), and their oxyR mutants. The one-, three-, and ninefold dilutions (1×, $3 \times$ and $9 \times)$ of the bacterial suspension were spotted onto nutrient-rich (NB) medium containing $0,0.0125,0.025,0.05$, and $0.1 \mathrm{mM} \mathrm{H}_{2} \mathrm{O}_{2}$. Strains were grown and treated in $\mathrm{NB}$ medium. Values are means \pm standard deviation (SD) of three biological replicates, and asterisks $(*)$ indicate $P$ value $<0.05(t$ test). For B and $\mathrm{C}$, expression was assessed by quantitative reverse-transcription polymerase chain reaction. Relative mRNA levels of tested genes in ZJ173 and RS105 when treated with acetone were used as control and were set at 1 . For D and E, total antioxidant capacity and total catalase activity was measured from total protein extract. Values are means $\pm \mathrm{SD}$ of three biological replicates, and asterisks $\left(^{*}\right)$ indicate $P$ value $<0.05(t$ test $)$. 
pv. oryzicola $\mathrm{RS} 105$. However, sensitivity of RS105-oxyR ${ }^{\mathrm{ZJ173}}$ to exogenous $\mathrm{H}_{2} \mathrm{O}_{2}$ was much greater than the wild-type strain $X$. oryzae pv. oryzicola RS105. Combined with the results above, it suggested that the ability of OxyR to induce gene expression in antioxidant systems may be stronger in $X$. oryzae pv. oryzicola than $X$. oryzae pv. oryzae, which contribute to higher total antioxidant ability and total CAT activity in it and, thus, ultimately increased the bacterium's ability to defend against oxidative stress. The results also indicated that OxyR could be a key protein contributing to the different sensitivities of $X$. oryzae pvs. oryzae and oryzicola to $\mathrm{H}_{2} \mathrm{O}_{2}$ that has never been reported before. However, it is noteworthy that the differences in target gene promoters and DNA binding ability and stability of OxyR may also contribute to the difference in the sensitivity of $X$. oryzae pvs. oryzae and oryzicola. When oxyR was absent or was obtained from $X$. oryzae pv. oryzae ZJ173, the ability to scavenge ROS that had accumulated in response to PCA treatment was decreased, so that sensitivity to PCA was increased in the mutants $\Delta \mathrm{Z}($ oxyR $), \Delta \mathrm{R}($ oxyR $)$, and RS105-oxy $R^{\mathrm{ZJ} 173}$. Although we expected that the mutant $\mathrm{ZJ} 173-$ oxy $R^{\mathrm{RS} 105}$ would have increased resistance to PCA, that was not the case (Fig. 3B; Table 3). The antioxidant capacity was increased but the levels of ROS remained high, even though the levels were lower than in the wild-type strain ZJ173 (Fig. 4). On the one hand, this suggested that OxyR is necessary for protecting $X$. oryzae pvs. oryzae and oryzicola from PCA stress. However, on the other hand, it may not be possible to increase the resistance to PCA of $X$. oryzae pv. oryzae though exchanging OxyR of $X$. oryzae pv. oryzicola. As noted earlier, phenazines are thought to mainly act as electron acceptors that disturb redox homeostasis (PriceWhelan et al. 2006; Rabaey et al. 2005; Yano et al. 2011). The mechanism of resistance to PCA may be much more complicated than we thought and needs to be further investigated in the future. Unexpectedly, the $\operatorname{oxy} R$ mutants of $X$. oryzae pvs.

A

$$
1 \times 3 \times 9 \times \quad 1 \times 3 \times 9 \times
$$

$1 \times 3 \times 9 \times$

$1 \times 3 \times 9 \times$

$1 \times 3 \times 9 \times$

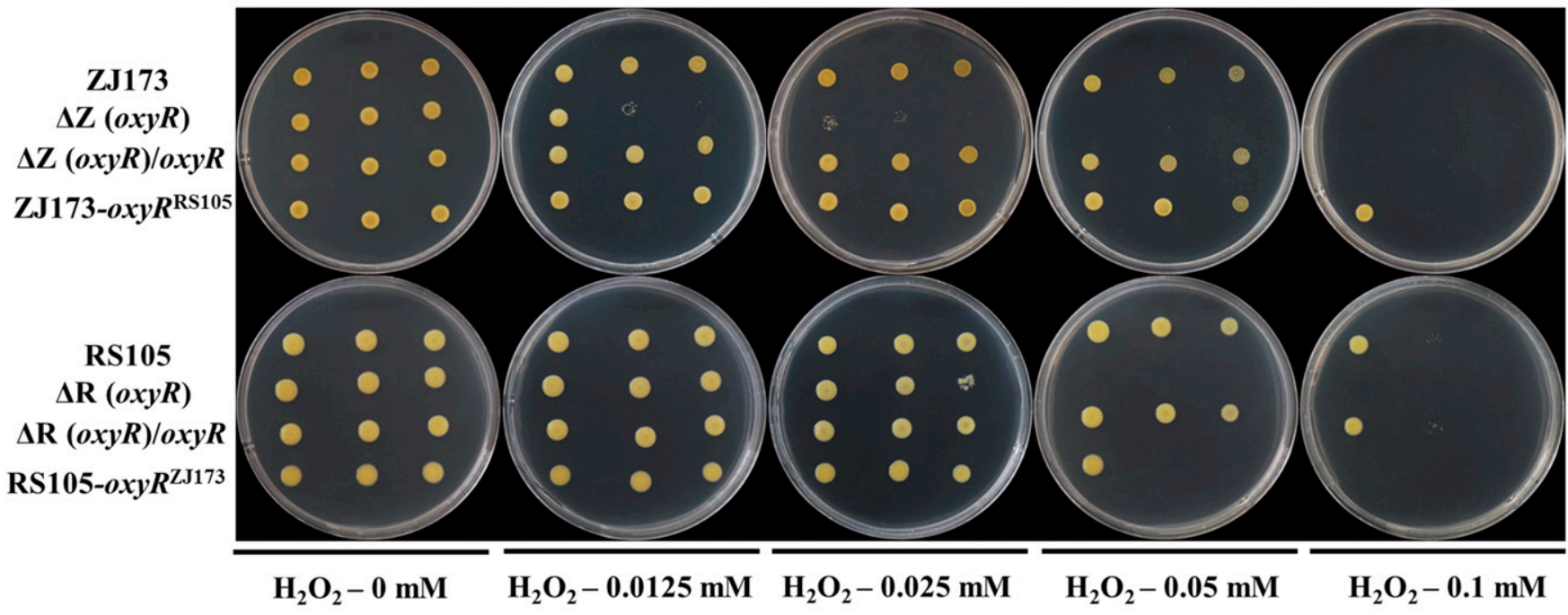

B

$1 \times 3 \times 9 \times$

$1 \times 3 \times 9 \times$

$1 \times 3 \times 9 \times$
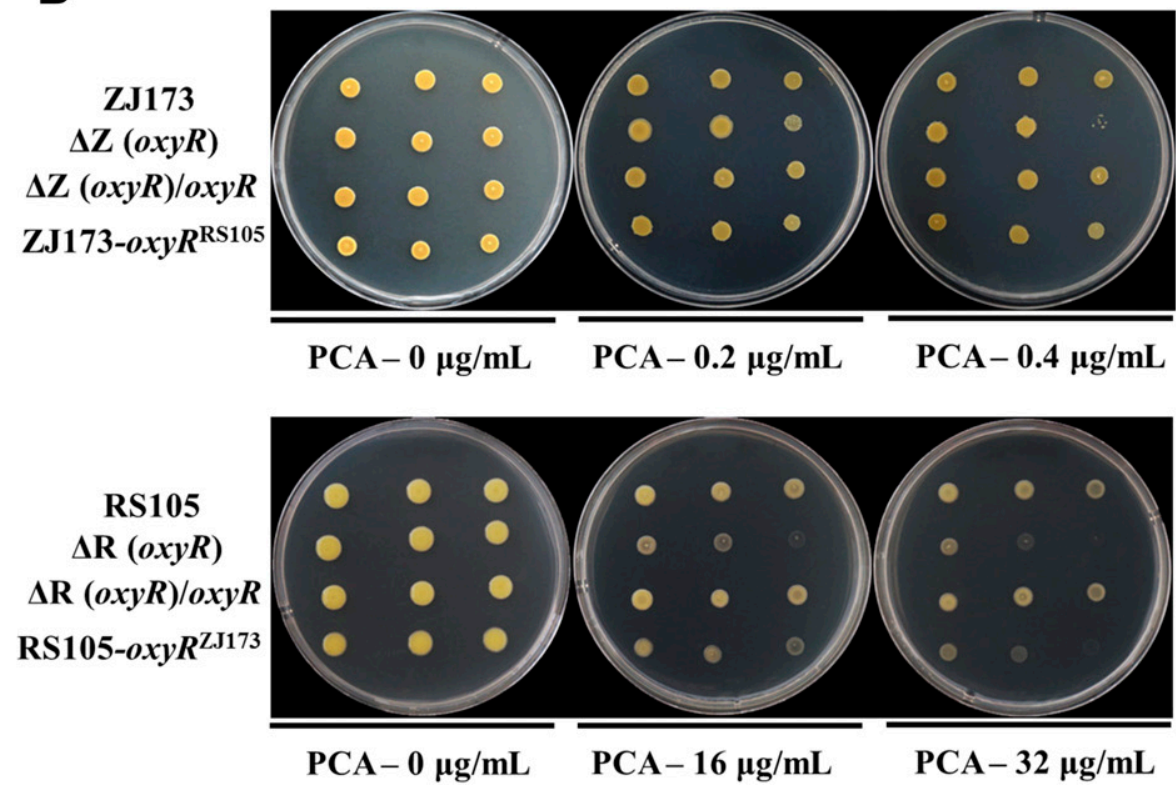

Fig. 3. A, $\mathrm{H}_{2} \mathrm{O}_{2}$ sensitivity and $\mathbf{B}$, phenazine-1-carboxylic acid (PCA) sensitivity of Xanthomonas oryzae pv. oryzae ZJ173 (wild type), X. oryzae pv. oryzicola

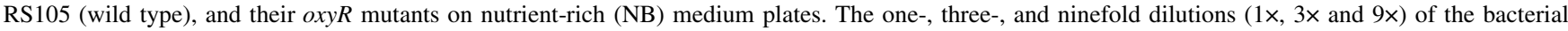
suspension were spotted onto NB medium. For A, NB medium contained $0,0.0125,0.025,0.05$, and $0.1 \mathrm{mM} \mathrm{H}_{2} \mathrm{O}_{2}$. For B, NB medium contained PCA at $0,0.2$, and $0.4 \mu \mathrm{g} / \mathrm{ml}$ for ZJ173 and PCA at 0,16 , and $32 \mu \mathrm{g} / \mathrm{ml}$ for RS105. 
oryzae and oryzicola showed no obvious difference from their wild-type strains in the presence of paraquat (the superoxide generator) and heavy metals $\left(\mathrm{Cu}^{2+}\right.$ and $\left.\mathrm{Fe}^{3+}\right)$ (Supplementary Fig. S3). A similar phenomenon has been reported before in Ralstonia solanacearum and P. aeruginosa. In $R$. solanacearum, the $\operatorname{oxy} R$ deletion mutant was more sensitive to $\mathrm{H}_{2} \mathrm{O}_{2}$ but grew better than the wild-type strain in the presence of paraquat (Flores-Cruz and Allen 2011). In P. aeruginosa, the oxyR deletion mutant didn't differ in growth on casamino acid plates containing $50 \mu \mathrm{M} \mathrm{FeCl}_{3}$ (Vinckx et al. 2008). We also found that $\operatorname{sox} R$ deletion mutants of $X$. oryzae pvs. oryzae and oryzicola weren't more sensitive to $\mathrm{H}_{2} \mathrm{O}_{2}$ than their wild-type strains (data not shown). These results suggested that the antioxidant system mediated by OxyR is not involved in the scavenging of oxidative stress induced by paraquat and heavy metals in $X$. oryzae pvs. oryzae and oryzicola.

Loss of OxyR was previously reported to affect the growth of several species of bacteria (Chung et al. 2015; Maciver and Hansen 1996; Vinckx et al. 2008). In our study, the growth of oxy $R$ deletion mutants of $X$. oryzae pvs. oryzae and oryzicola was blocked or reduced in MMX medium but was not significantly reduced in NB medium. This was not surprising because prolonged starvation may disturb the cellular ROS homeostasis, and restoring the homeostasis may be difficult or impossible for oxyR-defective mutants. ROS is also an important component of immune responses of plants against pathogen infection (Dubbs and Mongkolsuk 2012; Orozco-Cárdenas et al. 2001).

Table 3. Phenazine-1-carboxylic acid (PCA) sensitivity of Xanthomonas oryzae pv. oryzae (ZJ173) and X. oryzae pv. oryzicola (RS105)

\begin{tabular}{lr}
\hline Strain & $\mathbf{E C}_{\mathbf{5 0}}(\boldsymbol{\mu g} / \mathbf{m l})^{\mathbf{z}}$ \\
\hline ZJ173 & $\mathbf{0 . 2 1} \pm \mathbf{0 . 0 3 2} \mathbf{~ a}$ \\
$\Delta Z /$ oxy $R$ & $0.098 \pm 0.014 \mathrm{~b}$ \\
$\Delta Z /$ oxy $R /($ oxy $R)$ & $0.19 \pm 0.011 \mathrm{a}$ \\
ZJ173-oxyR $R^{\mathrm{RS} 105}$ & $0.23 \pm 0.020 \mathrm{a}$ \\
RS105 & $\mathbf{1 4 . 5 6} \pm \mathbf{1 . 8 9} \mathbf{a}$ \\
$\Delta R /$ oxy $R$ & $3.82 \pm 0.53 \mathrm{~b}$ \\
$\Delta R /$ oxy $/($ oxyR $)$ & $13.69 \pm 1.77 \mathrm{a}$ \\
RS105-oxyR $R^{\text {ZJ173 }}$ & $4.47 \pm 0.38 \mathrm{~b}$ \\
\hline
\end{tabular}

${ }^{\mathrm{z}} \mathrm{EC}_{50}=$ the concentration of PCA that resulted in 50\% inhibition of bacterial cell growth. Values are means \pm standard error of three experiments. Means with different letters are significantly different at $P<$ 0.05. Bold indicates wild-type strains.
The reduced virulence and bacterial numbers of $\Delta \mathrm{Z}($ oxy $R), \Delta \mathrm{R}$ $\left(\right.$ oxyR), and RS105-oxy $R^{\mathrm{ZJ} 173}$ and the enhanced virulence and bacterial numbers of ZJ173-oxy $R^{\mathrm{RS} 105}$ indicate that OxyR in $X$. oryzae pvs. oryzae and oryzicola might modulate the levels of ROS generated during bacterial infection. OxyR was also confirmed to be required for the pathogenicity of DC3000 on Arabidopsis (Ishiga and Ichinose 2016). In addition, our results showed that OxyR in $X$. oryzae pvs. oryzae and oryzicola was associated with the HR in the nonhost $N$. benthamiana. Plants can exploit the vulnerability of bacteria to ROS by generating ROS as part of the oxidative burst and thereby initiating an important defense response (Apel and Hirt 2004; Lamb and Dixon 1997). The HR response of $N$. benthamiana to RS105 and $\mathrm{ZJ} 173-$ oxy $R^{\mathrm{RS} 105}$ was relatively weak because these bacteria have a powerful antioxidation system that can effectively scavenge the ROS generated by the plant. Conversely, the HR response of $N$. benthamiana to $\mathrm{ZJ} 173, \Delta \mathrm{Z}($ oxyR $), \Delta \mathrm{R}($ oxyR), and RS105-oxy $R^{\mathrm{ZJ173}}$ was strong.

In conclusion, our results indicated that $X$. oryzae pv. oryzicola has a stronger antioxidant system than $X$. oryzae pv. oryzae and accumulates lower levels of ROS in response to redox compounds, which is proposed in Figure 6. As a consequence, $X$. oryzae pv. oryzae is more sensitive than $X$. oryzae pv. oryzicola to redox compounds. Our findings also highlight the significance of OxyR, which relates to the difference in antioxidant ability between $X$. oryzae pvs. oryzae and oryzicola and the difference in their sensitivity to PCA. Although OxyR in $X$. oryzae pvs. oryzae and oryzicola differs in 10 amino acids, which amino acids are responsible for the observed difference in OxyR activity remains to be determined. Our results also showed that OxyR is important for their virulence and for their induction of HR in host and nonhost plants.

\section{MATERIALS AND METHODS}

Bacterial strains, plasmids, growth conditions, and bactericides.

Bacterial strains, plasmids, and primers used in this study are listed in Table 4 and Supplementary Table S1. Strains ZJ173 of $X$. oryzae pv. oryzae and RS105 of X. oryzae pv. oryzicola are commonly used by researchers in China and are used as the parent strains in this study. X. oryzae pvs. oryzae and oryzicola wild-type strains, oxyR mutants, and their complemented
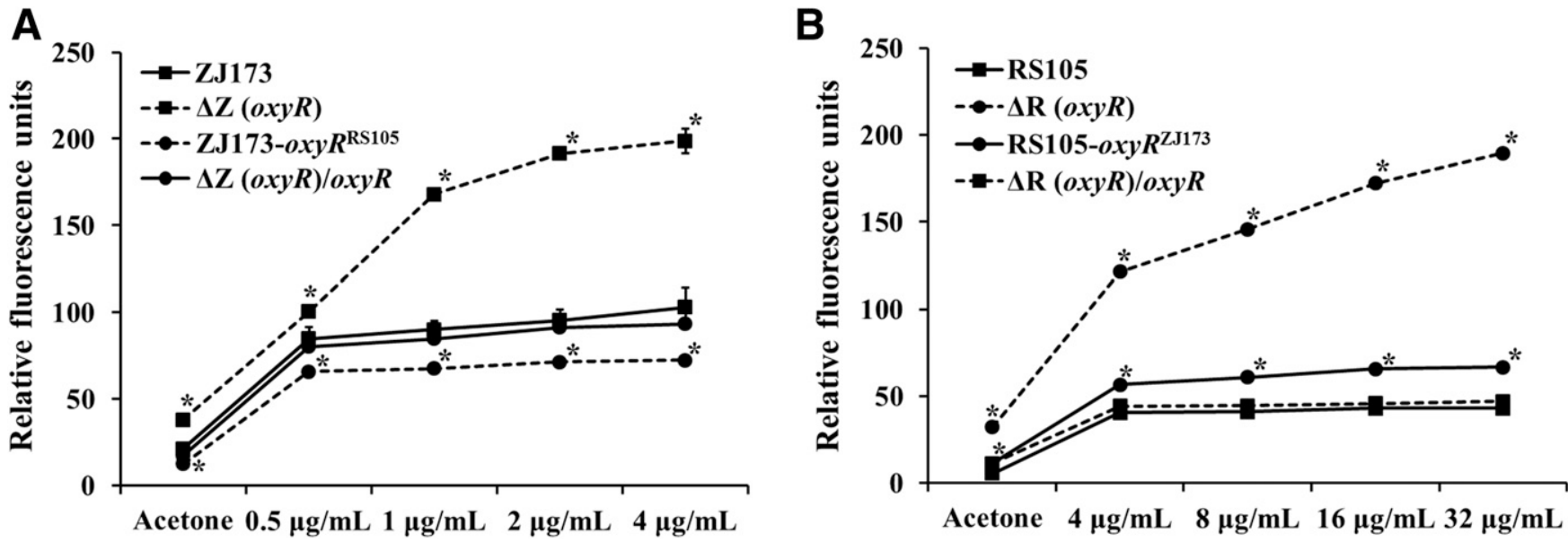

Fig. 4. Reactive oxygen species (ROS) accumulation in A, Xanthomonas oryzae pv. oryzae strains and $\mathbf{B}, X$. pv. oryzicola strains when stimulated with phenazine-1-carboxylic acid (PCA) $(0.5,1,2$, and $4 \mu \mathrm{g} / \mathrm{ml}$ for $X$. oryzae pv. oryzae strains and $4,8,16$, and $32 \mu \mathrm{g} / \mathrm{ml}$ for $X$. oryzae pv. oryzicola strains). Acetone was used as solvent control. Relative fluorescence units were the ROS accumulation in strains after $4 \mathrm{~h}$ at the excitation wavelength of $488 \mathrm{~nm}$ and the emission wavelength of $525 \mathrm{~nm}$. Relative fluorescence units in X. oryzae pv. oryzae ZJ173 or X. oryzae pv. oryzicola RS105 at the same concentration of PCA were used as control. Values are the means \pm standard deviation of three replicates, and asterisks $(*)$ indicate $P$ value $<0.05(t$ test). 
strains were cultured in NB medium (beef extract at $3 \mathrm{~g} / \mathrm{liter}$, polypeptone at $5 \mathrm{~g} / \mathrm{liter}$, yeast extract at $1 \mathrm{~g} / \mathrm{liter}$, and sucrose at $10 \mathrm{~g} /$ liter), with shaking at $175 \mathrm{rpm}$ and $28^{\circ} \mathrm{C}$. NB agar (NA) was used as a solid medium. MMX used for determination of growth rate contained trisodium citrate at $1 \mathrm{~g} /$ liter, glucose at $5 \mathrm{~g} /$ liter, $\left(\mathrm{NH}_{4}\right) \mathrm{SO}_{4}$ at $2 \mathrm{~g} / \mathrm{liter}, \mathrm{MgSO}_{4} \cdot 7 \mathrm{H}_{2} \mathrm{O}$ at $0.2 \mathrm{~g} / \mathrm{liter}$, $\mathrm{K}_{2} \mathrm{HPO}_{4}$ at $4 \mathrm{~g} /$ liter, and $\mathrm{KH}_{2} \mathrm{PO}_{4}$ at $6 \mathrm{~g} /$ liter. Escherichia coli $\mathrm{DH} 5 \alpha$ (Vazyme) was grown in Luria-Bertani (LB) $(\mathrm{NaCl}$ at 10 $\mathrm{g} /$ liter, typtone at $10 \mathrm{~g} / \mathrm{liter}$, and yeast extract at $5 \mathrm{~g} / \mathrm{liter}$ ) or on LB agar plates containing kanamycin at $50 \mu \mathrm{g} / \mathrm{ml}$ and $37^{\circ} \mathrm{C}$.

PCA (98\%; Shanghai Nongle Biological Products Co., Ltd.) was dissolved in acetone. The 99\% PHZ and 95\% 1-OH-PHZ were provided by TCI (Shanghai) Development Co., Ltd. and were dissolved in alcohol. Bismerthiazol (98\%; Longwan Agrichemical Co., Ltd.) was dissolved in N,N-dimethylformamide. Streptomycin (98\%; Sinopharm Chemical Reagent Co., Ltd.) was dissolved in water. Captan (95\%) was stored in our laboratory and was dissolved in acetone.

\section{Phenazines, paraquart, $\mathrm{H}_{2} \mathrm{O}_{2}$, and heavy metals sensitivity assays.}

The sensitivities of $X$. oryzae pvs. oryzae and oryzicola to phenazines, paraquat, $\mathrm{H}_{2} \mathrm{O}_{2}$, and heavy metals $\left(\mathrm{Cu}^{2+}\right.$ and $\left.\mathrm{Fe}^{3+}\right)$ were determined as previously described (Pan et al. 2017). The strains were grown in NB medium with shaking $(175 \mathrm{rpm})$ at $28^{\circ} \mathrm{C}$ to an optical density (OD) of $1.0\left(10^{9} \mathrm{CFU} / \mathrm{ml}\right)$. A $2-\mu \mathrm{l}$
A

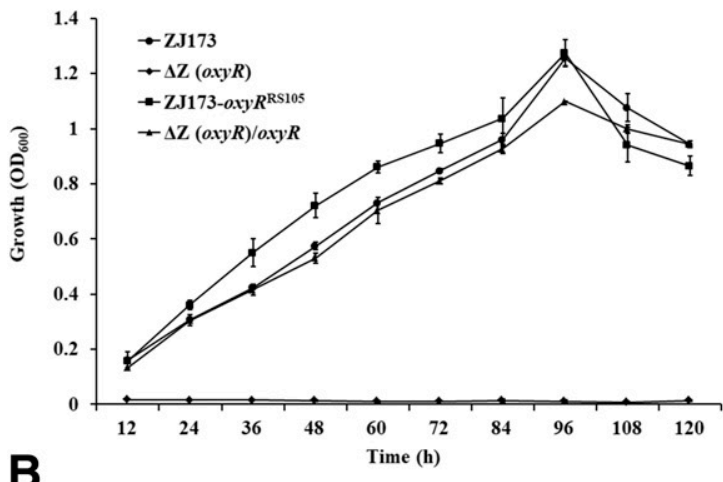

B

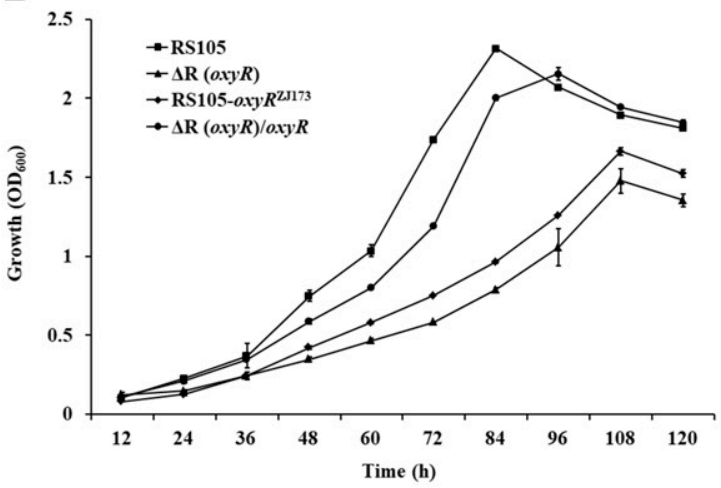

C

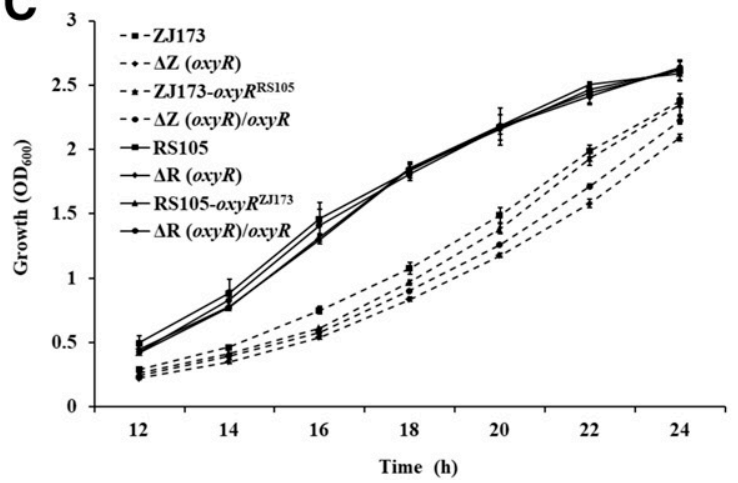

D
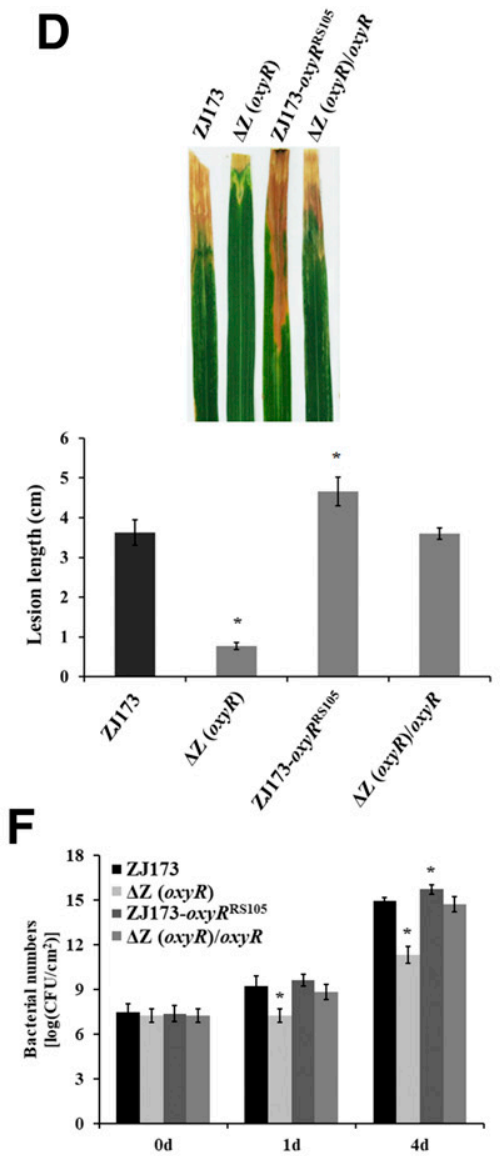

G

H
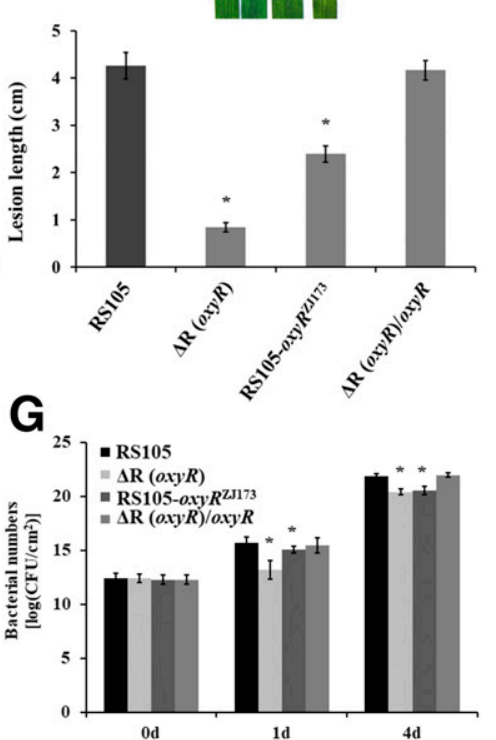

E
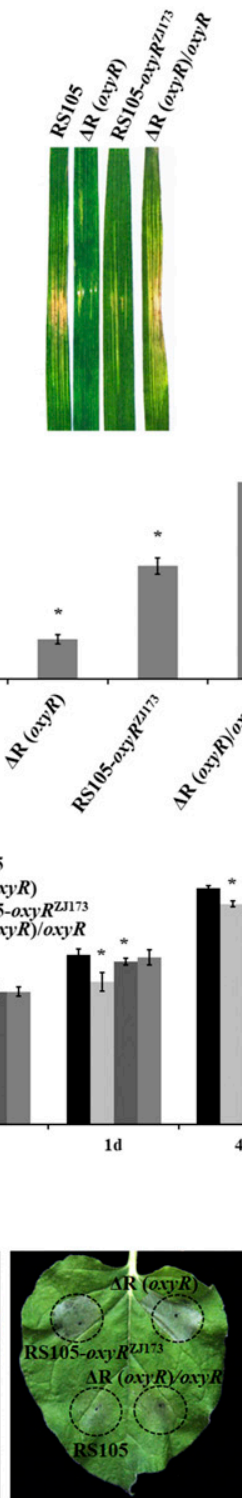

Fig. 5. Growth rate of A, Xanthomonas oryzae pv. oryzae ZJ173 (wild type) and its oxyR mutants; B, X. oryzae pv. oryzicola RS105 (wild type) and its oxyR mutants in a nutrient-poor (MMX) medium; and C, $X$. oryzae pv. oryzae ZJ173 (wild type), X. oryzae pv. oryzicola RS105 (wild type), and their oxyR mutants in a nutrient-rich $(\mathrm{NB})$ medium, as indicated by optical density at $600 \mathrm{~nm}\left(\mathrm{OD}_{600}\right)$. $\mathrm{OD}_{600}$ was measured every $12 \mathrm{~h}$ in MMX medium and every $2 \mathrm{~h}$ in $\mathrm{NB}$ medium. Values are means \pm standard deviation (SD) of three biological replicates, and asterisks (*) indicate $P$ value $<0.05$ ( $t$ test). Pathogenicity of $\mathbf{D}, X$. oryzae pv. oryzae strains and $\mathbf{E}, X$. oryzae pv. oryzicola strains in rice IR24. Bar charts show lesion lengths. Three replicates were used for each treatment, and the experiment was repeated three times. Bacterial numbers of $\mathbf{F}, X$. oryzae pv. oryzae strains and $\mathbf{G}, X$. oryzae pv. oryzicola strains in rice IR24. Three replicates were used for each treatment, and the experiment was repeated twice. Values are the means \pm SD of three replicates, and asterisks $(*)$ indicate $P$ value $<0.05$ ( $t$ test). Hypersensitive response assay of F, X. oryzae pv. oryzae ZJ173 (wild type); G, X. oryzae pv. oryzicola RS105 (wild type); and H, their oxyR mutants in Nicotiana benthamiana. Tested strains were infiltrated in to the leaves of $N$. benthamiana by using a needleless syringe. Necrosis was indicated by a dotted circle. 
volume of bacterial suspension was spotted on NA plates containing different concentrations of phenazines, paraquat, $\mathrm{H}_{2} \mathrm{O}_{2}, \mathrm{CuSO}_{4}$, or $\mathrm{FeCl}_{3}$. The final concentrations of PCA were 0.2 and $0.4 \mu \mathrm{g} / \mathrm{ml}$ for $X$. oryzae pv. oryzae and 16 and $32 \mu \mathrm{g} / \mathrm{ml}$ for $X$. oryzae pv. oryzicola. The concentrations of paraquat and $\mathrm{H}_{2} \mathrm{O}_{2}$ were $0.0125,0.025,0.05$, and $0.1 \mathrm{mM}$ for both bacteria. The concentrations of $\mathrm{Cu}^{2+}$ were $0.1,0.2$, and $0.4 \mathrm{mM}$ for $X$. oryzae pv. oryzae and $0.02,0.04$, and $0.06 \mathrm{mM}$ for $X$. oryzae pv. oryzicola. The concentrations of $\mathrm{Fe}^{3+}$ were $0.2,0.4$, and $0.6 \mathrm{mM}$ for $X$. oryzae pv. oryzae and $0.1,0.2$, and $0.4 \mathrm{mM}$ for $X$. oryzae pv. oryzicola. The plates were incubated at $28^{\circ} \mathrm{C}$ for 3 days (X. oryzae pv. oryzicola) or 4 days (X. oryzae pv. oryzae). The $\mathrm{EC}_{50}$ of PCA against $X$. oryzae pvs. oryzae and oryzicola was measured as follows. Bacterial cultures (OD at $600 \mathrm{~nm}\left[\mathrm{OD}_{600}\right]=1.0$ ) were adjusted to $\mathrm{OD}_{600}=0.2$ with fresh NB medium, and $120 \mu \mathrm{l}$ of the diluted bacterial suspensions and $100 \mu \mathrm{l}$ of PCA were subsequently added into $25 \mathrm{ml}$ of fresh NB medium. The concentrations of PCA were $0,0.0125,0.025$, $0.05,0.1,0.2$, or $0.4 \mu \mathrm{g} / \mathrm{ml}$ for $X$. oryzae pv. oryzae strains and $0,1,2,4,8,16$, or $32 \mu \mathrm{g} / \mathrm{ml}$ for $X$. oryzae $\mathrm{pv}$. oryzicola strains. The final acetone concentration was $0.4 \%$ (vol/vol). Three replicates were conducted for each treatment. The $\mathrm{OD}_{600}$ values were measured after 36 and $24 \mathrm{~h}$ of incubation $\left(28^{\circ} \mathrm{C}\right.$ with shaking at $175 \mathrm{rpm}$ ) for $X$. oryzae pvs. oryzae and oryzicola, respectively. The $\mathrm{EC}_{50}$ values were assessed by the Data Processing System (Hangzhou Reifeng Information Technology Ltd.). The experiments were performed three times.

\section{Real-time qRT-PCR and RNA-Seq.}

RNA isolation and qRT-PCR were performed as previously described (Pan et al. 2017). All strains were grown to an OD of $0.5\left(5 \times 10^{8} \mathrm{CFU} / \mathrm{ml}\right)$, and a 2 -ml volume of bacterial suspension was harvested by centrifugation $(8,000 \times g$ for $2 \mathrm{~min}$ at $4^{\circ} \mathrm{C}$ ). Total RNA was extracted using the RNAprep pure cell/bacteria kit (TIANGEN Biotech) according to the manufacturer's protocol. A 500-ng quantity of total RNA eliminated genomic DNA (gDNA) with $2 \mu \mathrm{l}$ of $4 \times \mathrm{gDNA}$ wiper $\operatorname{mix}\left(42^{\circ} \mathrm{C}\right.$, $2 \mathrm{~min}$ ). Then, the RNA was reverse transcribed to cDNA with $2 \mu \mathrm{l}$ of $5 \times$ qRT supermix II of the Hiscript Q RT supermix for qPCR kit (Vazyme). The cDNA was used as template of qRT-PCR which was conducted using the ChamQ SYBR qPCR Maser Mix kit (Vazyme) with a CFX Connect RealTime System (Bio-Rad Laboratories). Gene expression of oxyR (XOO3647/XOC_0957), soxR (XOO1257/XOC_1405), ankB (XOO0418/XOC_4324), catB (XOO0417/XOC_4325), katE (XOO3423/XOC_1265), srpA (XOO0447/XOC_4290), katG (XOC_3410), trxA (XOO0040/XOC_0180), ahpC (XOO3645/XOC_0959), ahpF (XOO3646/XOC_0958), sodB (XOO3208/XOC_2909), sodC2 (XOO4481/XOC_0298), sodM1 (XOO2712/XOC_2116), sodM2 (XOO2828/XOC_2312), and yojM (XOO4482/XOC_0299) was assessed. 16S ribosomal RNA was used as endogenous control. RNA-seq was conducted by Novogene Bioinformatics Technology. RNA sample testing, sequencing, and data analysis were performed according to a previous study (Liang et al. 2018). RNA-seq profiles of PCAtreated $(4 \mu \mathrm{g} / \mathrm{ml})$ and acetone-treated $X$. oryzae pv. oryzae and acetone-treated $X$. oryzae pv. oryzicola are shown in Supplementary Fig. S2.

\section{Generation of oxyR mutants.}

Xoo3647 (oxyR in X. oryzae pv. oryzae) and Xoc_0957 (oxyR in $X$. oryzae pv. oryzicola) were deleted by nonmarker

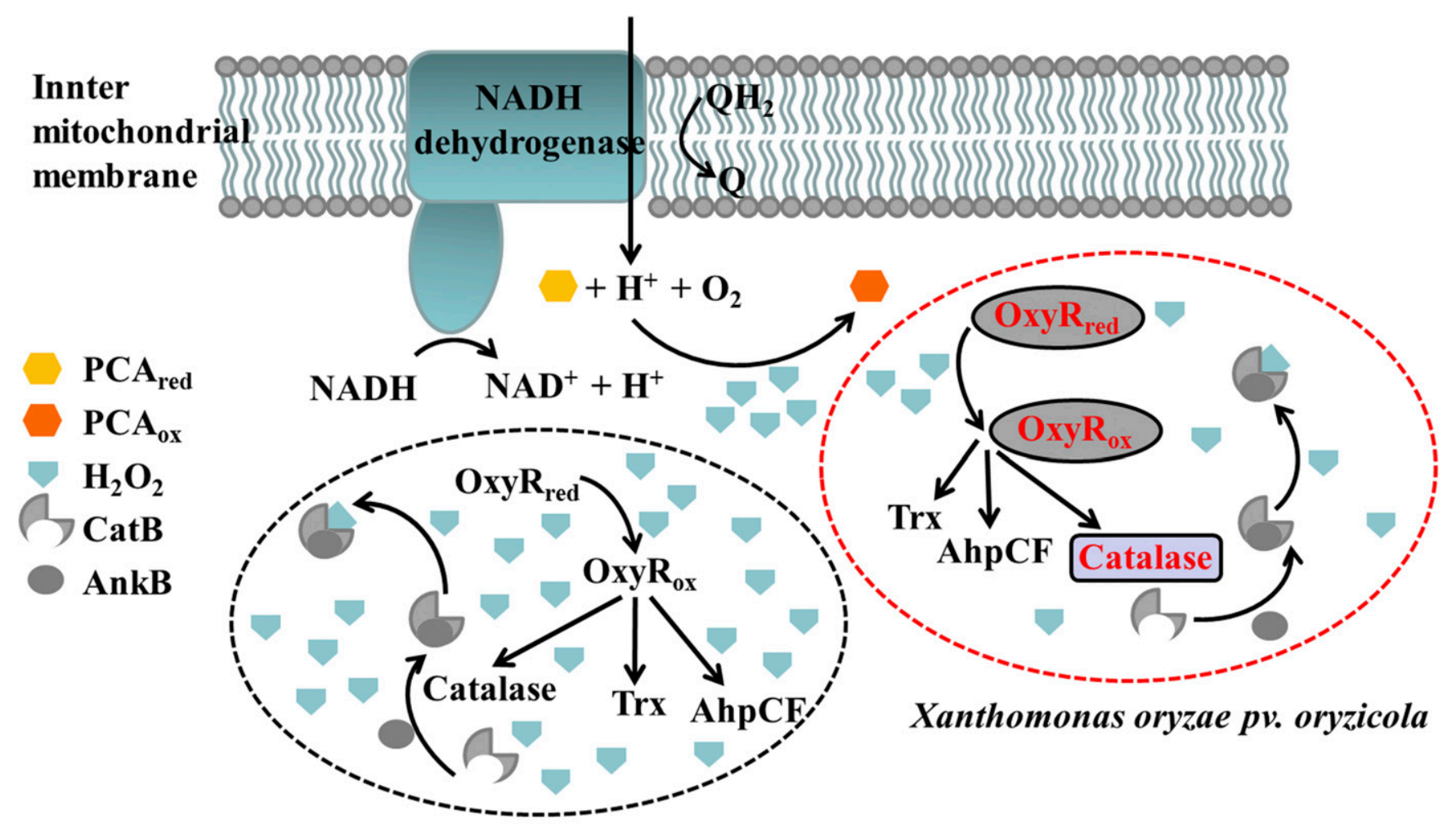

Xanthomonas oryzae pv. oryzae

Fig. 6. Model showing different responses to oxidative stress in Xanthomonas oryzae pv. oryzae versus X. oryzae pv. oryzicola. Reactive oxygen species (ROS) are generated by oxidation of phenazine-1-carboxylic acid (PCA) $\left(\mathrm{PCA}_{\text {red }}=\right.$ reduction of PCA and $\mathrm{PCA}_{\mathrm{ox}}=$ oxidation of PCA) (Wang and Newman 2008). Here, we take hydrogen peroxide $\left(\mathrm{H}_{2} \mathrm{O}_{2}\right)$ as an example. OxyR senses oxidative stress induced by PCA treatment or plants during their infection and, in turn, activates the antioxidant systems to remove $\mathrm{H}_{2} \mathrm{O}_{2}$ in the two bacteria. The antioxidant systems regulated by OxyR are much greater in $X$. oryzae pv. oryzicola (right circle) than in $X$. oryzae pv. oryzae (left circle). Ultimately, less $\mathrm{H}_{2} \mathrm{O}_{2}$ is accumulated in the bacterial cells of $X$. oryzae pv. oryzicola. 
homologous recombination, as previously described (Qian et al. 2013). In brief, an upstream and a downstream fragment of oxyR in ZJ173 or RS105 were amplified by PCR using the primer pairs ZoxyR-1F/1R and ZoxyR-2F/2R or RoxyR-1F/1R and RoxyR-2F/2R, respectively, and the fragments were then cloned into the suicide vector $\mathrm{pK} 18 \mathrm{mobSacB}$. The recombinant plasmid pK18ZOR or pK18ROR was introduced into ZJ173 or RS105, respectively, by electroporation. Transformants were isolated on NA medium without sucrose containing kanamycin at $20 \mu \mathrm{g} / \mathrm{ml}$. After they were incubated in $25 \mathrm{ml}$ of NB medium without sucrose for 7 to $9 \mathrm{~h}$ at $28^{\circ} \mathrm{C}$, and the transformants were spread on NA medium containing sucrose at $100 \mu \mathrm{g} / \mathrm{ml}$. The positive colonies were confirmed by PCR using primer pairs ZoxyR-1F/2R and RoxyR-1F/2R, respectively. Plasmid pUFR034 was used to construct replacement and complemented mutants. A 1,119-bp fragment carrying the full length of $\operatorname{oxy} R$ with its promoter region was amplified from the gDNA of ZJ173 or RS105 with primer pair Z/oxyRH-F/R, respectively. The fragment was then fused to pUFR034. To construct complemented mutants, the recombinant plasmid pUFRZOR or pUFRROR was then introduced into the $o x y R$ deletion mutants of ZJ173 or RS105, respectively. To construct replacement mutants, the recombinant plasmid pUFRROR or pUFRZOR was introduced into $o x y R$ deletion mutants of ZJ173 or RS105, respectively. The complemented and replacement mutants were all obtained using the electroporation method; they were screened on NA plates containing kanamycin at $20 \mu \mathrm{g} / \mathrm{ml}$, and were then confirmed by PCR using primer pair Z/oxyRH-F/R.

\section{Total antioxidant capacity assay.}

The tested strains were grown at $28^{\circ} \mathrm{C}$ overnight in NB medium $\left(\mathrm{OD}_{600}=1.0\right)$. Bacterial cells were collected from $2 \mathrm{ml}$ of culture suspension by centrifugation $(4,000 \times g$ for $2 \mathrm{~min})$ and were resuspended in $500 \mu \mathrm{l}$ of precooling phosphatebuffered saline (1 liter: $137 \mathrm{mM} \mathrm{NaCl}, 2.7 \mathrm{mM} \mathrm{KCl}, 10 \mathrm{mM}$ $\mathrm{Na}_{2} \mathrm{HPO}_{4}$, and $2 \mathrm{mM} \mathrm{NaH} \mathrm{PO}_{4} ; \mathrm{pH}$ 7.4). The cells were subjected to ultrasonication for $40 \mathrm{~s}$ (amplitude 15\%, ultrasound 1 $\mathrm{s}$, pause $3 \mathrm{~s}$ ). The supernatant was then collected by centrifugation $\left(12,000 \times g\right.$ for $5 \mathrm{~min}$ at $\left.4^{\circ} \mathrm{C}\right)$, and the protein concentration was determined with the BCA Protein Concentration Determination Kit (Beyotime). Total antioxidant capacity was then determined with the Total antioxidant capacity assay kit (Beyotime). Each treatment was represented by three replicates, and the experiment was conducted three times. The results were analyzed with SPSS 20.0 (independent-sample $t$ tests).

\section{CAT activity assay.}

CAT activity was assessed as previously described (Pan et al. 2017). In brief, bacterial cells were treated with $200 \mu \mathrm{l}$ of Western and IP Cell Lysis Liquid (Beyotime). The protein concentration in the supernatant was determined with the BCA Protein Concentration Determination Kit (Beyotime), and the total CAT activity was determined with the Catalase Test Kit (Beyotime), according to the manufacturer's protocol. The sampling volume of the supernatant was $40 \mu \mathrm{l}$ for ZJ173, $\Delta Z / o x y R, \Delta R / o x y R$, and RS105-oxyR $R^{\mathrm{ZJ} 173} ; 10 \mu \mathrm{l}$ for RS105; and $20 \mu \mathrm{l}$ for ZJ173-oxy $R^{\mathrm{RS} 105}$. The experiment was performed three times, and each independent experiment included three replicates. The results were analyzed with SPSS 20.0 (independentsample $t$ tests).

\section{ROS accumulation assay.}

ROS accumulation was quantified according to the protocol of an ROS assay kit (Beyotime), as previously described (Xu et al. 2015). The nonionic, nonpolar 2',7'-dichlorofluorescin diacetate (DCFH-DA) was used to detect ROS (Wang and Joseph 1999). In brief, bacterial cells were collected from $15 \mathrm{ml}$ of culture suspension $\left(\mathrm{OD}_{600}=1.0\right)$ by centrifugation $(5,000 \times g$ for $2 \mathrm{~min}$ ). The cells were then resuspended in $8 \mathrm{ml}$ of DCFH-DA solution and incubated for $20 \mathrm{~min}$ at $28^{\circ} \mathrm{C}$. After they were washed three times, the cells were resuspended in $6 \mathrm{ml}$ of fresh XOM medium (1 liter: $4.5 \mathrm{~g}$ of $\mathrm{KH}_{2} \mathrm{PO}_{4}, 1 \mathrm{~g}$ of $(\mathrm{NH} 4)_{2} \mathrm{SO}_{4}$, $1 \mathrm{mM} \mathrm{MgSO}$, $10.5 \mathrm{~g}$ of $\mathrm{K}_{2} \mathrm{HPO}_{4}, 20 \mathrm{mM}$ succinic acid, and $0.15 \%$ casein hydrolysate). The preparation was then divided into seven samples of $700 \mu$ per sample. Each sample was then treated with PCA before $200 \mu \mathrm{l}$ of the suspension was added to the wells of black microplates. The final concentrations of PCA were $0.5,1,2$, and $4 \mu \mathrm{g} / \mathrm{ml}$ for ZJ173 and $4,8,16$, and $32 \mu \mathrm{g} / \mathrm{ml}$

Table 4. Strains and plasmids used in this study

\begin{tabular}{|c|c|c|}
\hline Strains, plasmids, and primers & Characteristics $^{\mathrm{z}}$ & Source \\
\hline \multicolumn{3}{|l|}{ Strains } \\
\hline Escherichia coli $\mathrm{DH} 5 \alpha$ & 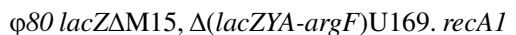 & Vazyme, Nanjing, China \\
\hline ZJ173 & $\begin{array}{l}\mathrm{Rif}^{\mathrm{R}} \text {, wild-type strain of Xanthomonas } \\
\text { oryzae pv. oryzae }\end{array}$ & Laboratory collection \\
\hline$\Delta Z / o x y R$ & $\begin{array}{l}\text { Rif }^{R} \text {, deletion of } \operatorname{oxyR} \text { in wild-type strain } \\
\text { ZJ173 }\end{array}$ & This study \\
\hline$\Delta Z / o x y R(\operatorname{oxy} R)$ & $\mathrm{Rif}^{\mathrm{R}}, \mathrm{Km}^{\mathrm{R}}$, complemented strain of $\Delta Z / o x y R$ & This study \\
\hline RS105 & $\begin{array}{l}\mathrm{Rif}^{\mathrm{R}} \text {, wild-type strain of } X \text {. oryzae } \mathrm{pv} \text {. } \\
\text { oryzicola }\end{array}$ & Laboratory collection \\
\hline$\Delta R / o x y R$ & $\begin{array}{l}\text { Rif }^{R} \text {, deletion of } \text { oxyR in wild-type strain } \\
\text { RS105 }\end{array}$ & This study \\
\hline$\Delta R / o x y R($ oxy $R)$ & $\mathrm{Rif}^{\mathrm{R}}, \mathrm{Km}^{\mathrm{R}}$, complemented strain of $\Delta R /$ oxy $R$ & This study \\
\hline \multicolumn{3}{|l|}{ Plasmids } \\
\hline pK18mobsacB & $\begin{array}{l}\mathrm{Km}^{\mathrm{R}} \text {, allelic exchange suicide vector, } s a c B \\
\text { oriT(RP4) }\end{array}$ & Laboratory collection \\
\hline pK18ZOR & $\begin{array}{l}\mathrm{Km}^{\mathrm{R}} \text {, a 2,094-bp fusion fragment of ZoxyR- } \\
\text { 1, ZoxyR-2gene ligated in pK18mobsacB }\end{array}$ & This study \\
\hline pK18ROR & $\begin{array}{l}\mathrm{Km}^{\mathrm{R}} \text {, a 2,269-bp fusion fragment of RoxyR- } \\
\text { 1, RoxyR-2gene ligated in pK18mobsacB }\end{array}$ & This study \\
\hline pUFR034 & $\begin{array}{l}\operatorname{lnc} W, \mathrm{Nm}^{\mathrm{R}}, \mathrm{Km}^{\mathrm{R}}, \operatorname{Mob}^{+}, \operatorname{Mob}(p), \operatorname{lacZ} \alpha \\
\text { PK2 replicon, cosmid }\end{array}$ & Laboratory collection \\
\hline PUFRZOR & $\begin{array}{l}\mathrm{Km}^{\mathrm{R}} \text {, a 1,119-bp fusion fragment of ZoxyR- } \\
\mathrm{H} \text { gene in ZJ173 ligated in pUFR034 }\end{array}$ & This study \\
\hline PUFRROR & $\begin{array}{l}\mathrm{Km}^{\mathbb{R}} \text {, a 1,119-bp fusion fragment of RoxyR- } \\
\mathrm{H} \text { gene in RS105 ligated in pUFR034 }\end{array}$ & This study \\
\hline
\end{tabular}

\footnotetext{
${ }^{\mathrm{z}} \mathrm{Rif}^{\mathrm{R}}, \mathrm{Km}^{\mathrm{R}}$, and $\mathrm{Nm}^{\mathrm{R}}=$ resistance to rifampicin, kanamycin, and neomycin, respectively.
} 
for RS105. The acetone concentration was $0.4 \%$ ( $\mathrm{vol} / \mathrm{vol}$ ) in all cases. ROS levels were determined by fluorescence, which was assessed with a fluorescence microplate reader every $20 \mathrm{~min}$ during a 4-h period. The excitation wavelength was $488 \mathrm{~nm}$ and the emission wavelength was $525 \mathrm{~nm}$. Each sample was assessed three times, and three independent experiments were performed.

\section{Growth rate assay.}

The tested strains were grown at $28^{\circ} \mathrm{C}$ overnight in NB medium $\left(\mathrm{OD}_{600}=1.0\right)$. Bacterial cells were collected from $2 \mathrm{ml}$ of culture suspension by centrifugation $(5,000 \times g$ for $2 \mathrm{~min}$ ) and were resuspended in $2 \mathrm{ml}$ of sterile water. A 2$\mathrm{ml}$ volume of cell suspension was then added to $100 \mathrm{ml}$ of $\mathrm{NB}$ medium or MMX medium. After the cell suspension was incubated for $12 \mathrm{~h}$, the bacterial growth dynamics were determined by measuring $\mathrm{OD}_{600}$ every $2 \mathrm{~h}$ in NB medium and every $12 \mathrm{~h}$ in MMX medium.

\section{HR assay.}

The tested strains were grown at $28^{\circ} \mathrm{C}$ overnight in $\mathrm{NB}$ medium. After the culture suspension was adjusted to an $\mathrm{OD}_{600}$ of $0.5\left(5 \times 10^{8} \mathrm{CFU} / \mathrm{ml}\right)$, it was infiltrated into the leaves of $N$. benthamiana by using a needleless syringe. The HR was assessed after 40 to $48 \mathrm{~h}$ of infiltration. Each strain was assayed three times, and three independent experiments were performed.

\section{Pathogenicity assay and determination of bacterial numbers in rice leaves.}

Pathogenicity assay was conducted as previously described (Pan et al. 2017). In brief, the tested strains were grown to an $\mathrm{OD}_{600}$ of $1.0\left(10^{9} \mathrm{CFU} / \mathrm{ml}\right)$. X. oryzae pvs. oryzae and oryzicola strains were inoculated into leaves of 6- and 8-week-old rice plants (IR24, a susceptible cultivar), respectively. The $X$. oryzae pv. oryzae suspension was inoculated into leaves that had been cut with sterile scissors, and the $X$. oryzae pv. oryzicola suspension was inoculated into leaves that had been pierced with sterile needles. Lesion lengths were scored at 12 dpi. For each experiment, three leaves on each of three plants were inoculated with each strain, and three independent experiments were performed. The average numbers of bacterial CFU per square centimeter in rice leaves inoculated with $X$. oryzae pvs. oryzae and oryzicola strains were determined immediately after inoculation and at 1 and $4 \mathrm{dpi}$. Then, $2 \mathrm{~cm}^{2}$ of each sample from inoculation sites was cut and surface sterilized in $5 \% \mathrm{H}_{2} \mathrm{O}_{2}$ for $30 \mathrm{~s}$. Sterilized samples were ground in $1 \mathrm{ml}$ of sterile water and serially diluted, and CFU numbers were determined after spreading and incubation. Each sample was cut three leaves. Each leaf represented a biological replicate, and the experiment was performed twice.

\section{LITERATURE CITED}

Apel, K., and Hirt, H. 2004. Reactive oxygen species: Metabolism, oxidative stress, and signal transduction. Annu. Rev. Plant Biol. 55:373-399.

Aslund, F., Zheng, M., Beckwith, J., and Storz, G. 1999. Regulation of the OxyR transcription factor by hydrogen peroxide and the cellular thioldisulfide status. Proc. Natl. Acad. Sci. U.S.A. 96:6161-6165.

Aznar, A., Chen, N. W., Thomine, S., and Dellagi, A. 2015. Immunity to plant pathogens and iron homeostasis. Plant Sci. 240:90-97.

Breitenbach, M., Weber, M., Rinnerthaler, M., Karl, T., and BreitenbachKoller, L. 2015. Oxidative stress in fungi: Its function in signal transduction, interaction with plant hosts, and lignocellulose degradation. Biomolecules 5:318-342.

Cabiscol, E., Tamarit, J., and Ros, J. 2000. Oxidative stress in bacteria and protein damage by reactive oxygen species. Int. Microbiol. 3:3-8.

Choi, H., Kim, S., Mukhopadhyay, P., Cho, S., Woo, J., Storz, G., and Ryu, S. E. 2001. Structural basis of the redox switch in the OxyR transcription factor. Cell 105:103-113.
Chung, C. H., Fen, S. Y., Yu, S. C., and Wong, H. C. 2015. Influence of oxyR on Growth, Biofilm Formation, and Mobility of Vibrio parahaemolyticus. Appl. Environ. Microbiol. 82:788-796.

Cooke, M. S., Evans, M. D., Dizdaroglu, M., and Lunec, J. 2003. Oxidative DNA damage: Mechanisms, mutation, and disease. FASEB J. 17: 1195-1214.

Dietrich, L. E., Teal, T. K., Price-Whelan, A., and Newman, D. K. 2008 Redox-active antibiotics control gene expression and community behavior in divergent bacteria. Science 321:1203-1206.

Du, X., Li, Y., Zhou, Q., and Xu, Y. 2015. Regulation of gene expression in Pseudomonas aeruginosa M18 by phenazine-1-carboxylic acid. Appl. Microbiol. Biotechnol. 99:813-825.

Dubbs, J. M., and Mongkolsuk, S. 2012. Peroxide-sensing transcriptional regulators in bacteria. J. Bacteriol. 194:5495-5503.

Flores-Cruz, Z., and Allen, C. 2011. Necessity of OxyR for the hydrogen peroxide stress response and full virulence in Ralstonia solanacearum. Appl. Environ. Microbiol. 77:6426-6432.

Fones, H., and Preston, G. M. 2012. Reactive oxygen and oxidative stress tolerance in plant pathogenic Pseudomonas. FEMS Microbiol. Lett. 327: $1-8$.

Heo, Y.-J., Chung, I.-Y., Cho, W.-J., Lee, B.-Y., Kim, J.-H., Choi, K.-H., Lee, J.-W., Hassett, D. J., and Cho, Y.-H. 2009. The major catalase gene (katA) of Pseudomonas aeruginosa PA14 is under both positive and negative control of the global transactivator OxyR in response to hydrogen peroxide. J. Bacteriol. 192:381-390.

Ieva, R., Roncarati, D., Metruccio, M. M., Seib, K. L., Scarlato, V., and Delany, I. 2008. OxyR tightly regulates catalase expression in Neisseria meningitidis through both repression and activation mechanisms. Mol. Microbiol. 70:1152-1165.

Imlay, J. A. 2015a. Diagnosing oxidative stress in bacteria: Not as easy as you might think. Curr. Opin. Microbiol. 24:124-131.

Imlay, J. A. 2015b. Transcription factors that defend bacteria against reactive oxygen species. Annu. Rev. Microbiol. 69:93-108.

Ishiga, Y., and Ichinose, Y. 2016. Pseudomonas syringae pv. tomato OxyR is required for virulence in tomato and Arabidopsis. Mol. Plant-Microbe Interact. 29:119-131.

Jaaffar, A. K. M., Parejko, J. A., Paulitz, T. C., Weller, D. M., and Thomashow, L. S. 2017. Sensitivity of Rhizoctonia Isolates to phenazine-1-carboxylic acid and biological control by phenazine-producing Pseudomonas spp. Phytopathology 107:692-703.

Kong, I.-S., Bates, T. C., Hülsmann, A., Hassan, H., Smith, B. E., and Oliver, J. D. 2004. Role of catalase and oxyR in the viable but nonculturable state of Vibrio vulnificus. FEMS Microbiol. Ecol. 50:133-142.

Lamb, C., and Dixon, R. A. 1997. The oxidative burst in plant disease resistance. Annu. Rev. Plant Physiol. Plant Mol. Biol. 48:251-275.

Lang, J. M., Hamilton, J. P., Diaz, M. G. Q., Sluys, M. A. V. M., Burgos, R. G., Cruz, C. M. V., Buell, C. R., Tisserat, N. A., and Leach, J. E. 2010. Genomics-based diagnostic marker development for Xanthomonas oryzae pv. oryzae and X. oryzae pv. oryzicola. Plant Dis. 94:311-319.

Liang, X., Yu, X., Pan, X., Wu, J., Duan, Y., Wang, J., and Zhou, M. 2018. A thiadiazole reduces the virulence of Xanthomonas oryzae pv. oryzae by inhibiting the histidine utilization pathway and quorum sensing. Mol. Plant Pathol. 19:116-128.

Liu, X., Sun, M., Cheng, Y., Yang, R., Wen, Y., Chen, Z., and Li, J. 2016. OxyR is a key regulator in response to oxidative stress in Streptomyces avermitilis. Microbiology 162:707-716.

Loprasert, S., Fuangthong, M., Whangsuk, W., Atichartpongkul, S., and Mongkolsuk, S. 2000. Molecular and physiological analysis of an OxyRregulated ahpC promoter in Xanthomonas campestris pv. phaseoli. Mol. Microbiol. 37:1504-1514.

Maciver, I., and Hansen, E. J. 1996. Lack of expression of the global regulator OxyR in Haemophilus influenzae has a profound effect on growth phenotype. Infect. Immun. 64:4618-4629.

Morales, D. K., Jacobs, N. J., Rajamani, S., Krishnamurthy, M., CubillosRuiz, J. R., and Hogan, D. A. 2010. Antifungal mechanisms by which a novel Pseudomonas aeruginosa phenazine toxin kills Candida albicans in biofilms. Mol. Microbiol. 78:1379-1392.

Niño-Liu, D. O., Ronald, P. C., and Bogdanove, A. J. 2006. Xanthomonas oryzae pathovars: Model pathogens of a model crop. Mol. Plant Pathol. 7:303-324.

Okegbe, C., Fields, B. L., Cole, S. J., Beierschmitt, C., Morgan, C. J., PriceWhelan, A., Stewart, R. C., Lee, V. T., and Dietrich, L. E. P. 2017. Electron-shuttling antibiotics structure bacterial communities by modulating cellular levels of c-di-GMP. Proc. Natl. Acad. Sci. U.S.A. 114: E5236-E5245.

Orozco-Cárdenas, M. L., Narváez-Vásquez, J., and Ryan, C. A. 2001. Hydrogen peroxide acts as a second messenger for the induction of 
defense genes in tomato plants in response to wounding, systemin, and methyl jasmonate. Plant Cell 13:179-191.

Ou, S. H. 1985. Rice Diseases. Commonwealth Agricultural Bureau, Kew, Surrey, United Kingdom.

Pan, X., Wu, J., Xu, S., Duan, Y., and Zhou, M. 2017. CatB is critical for total catalase activity and reduces bactericidal effects of phenazine-1carboxylic acid on Xanthomonas oryzae pv. oryzae and X. oryzae pv. oryzicola. Phytopathology 107:163-172.

Pomposiello, P. J., and Demple, B. 2001. Redox-operated genetic switches: The SoxR and OxyR transcription factors. Trends Biotechnol. 19:109-114.

Price-Whelan, A., Dietrich, L. E. P., and Newman, D. K. 2006. Rethinking 'secondary' metabolism: Physiological roles for phenazine antibiotics. Nat. Chem. Biol. 2:71-78.

Qian, G., Liu, C., Wu, G., Yin, F., Zhao, Y., Zhou, Y., Zhang, Y., Song, Z., Fan, J., Hu, B., and Liu, F. 2013. AsnB, regulated by diffusible signal factor and global regulator Clp, is involved in aspartate metabolism, resistance to oxidative stress and virulence in Xanthomonas oryzae pv. oryzicola. Mol. Plant Pathol. 14:145-157.

Rabaey, K., Boon, N., Höfte, M., and Verstraete, W. 2005. Microbial phenazine production enhances electron transfer in biofuel cells. Environ. Sci. Technol. 39:3401-3408.

Saleh, O., Gust, B., Boll, B., Fiedler, H. P., and Heide, L. 2009. Aromatic prenylation in phenazine biosynthesis: Dihydrophenazine-1-carboxylate dimethylallyltransferase from Streptomyces anulatus. J. Biol. Chem. 284:14439-14447.

Seo, S. W., Kim, D., Szubin, R., and Palsson, B. O. 2015. Genome-wide reconstruction of OxyR and SoxRS transcriptional regulatory networks under oxidative stress in Escherichia coli K-12 MG1655. Cell Rep. 12:1289-1299.

Seo, Y. S., Sriariyanun, M., Wang, L., Pfeiff, J., Phetsom, J., Lin, Y., Jung, K. H., Chou, H. H., Bogdanove, A., and Ronald, P. 2008. A two-genome microarray for the rice pathogens Xanthomonas oryzae pv. oryzae and $X$. oryzae pv. oryzicola and its use in the discovery of a difference in their regulation of hrp genes. BMC Microbiol. 8:99-110.

Singh, A. K., Shin, J. H., Lee, K. L., Imlay, J. A., and Roe, J. H. 2013. Comparative study of SoxR activation by redox-active compounds. Mol. Microbiol. 90:983-996.

Sporer, A. J., Kahl, L. J., Price-Whelan, A., and Dietrich, L. E. P. 2017. Redox-based regulation of bacterial development and behavior. Annu. Rev. Biochem. 86:777-797.

Storz, G., Tartaglia, L. A., Farr, S. B., and Ames, B. N. 1990. Bacterial defenses against oxidative stress. Trends Genet. 6:363-368.

Swings, J., Van Den Mooter, M., Vauterin, L., Hoste, B., Gillis, M., Mew, T. W., and Kersters, K. 1990. Reclassification of the causal agents of bacterial blight (Xanthomonas campestris pv. oryzae) and bacterial leaf streak (Xanthomonas campestris pv. oryzicola) of rice as pathovars of Xanthomonas oryzae (ex Ishiyama 1922) sp. nov., nom. rev. Int. J. Syst. Bacteriol. 40:309-311.
Thomashow, L. S., Weller, D. M., Bonsall, R. F., and Pierson, L. S. 1990. Production of the antibiotic phenazine-1-carboxylic Acid by fluorescent pseudomonas species in the rhizosphere of wheat. Appl. Environ. Microbiol. 56:908-912.

Tseng, H. J., McEwan, A. G., Apicella, M. A., and Jennings, M. P. 2003. OxyR acts as a repressor of catalase expression in Neisseria gonorrhoeae. Infect. Immun. 71:550-556.

Vázquez-Torres, A. 2012. Redox active thiol sensors of oxidative and nitrosative stress. Antioxid. Redox Signal. 17:1201-1214.

Vinckx, T., Matthijs, S., and Cornelis, P. 2008. Loss of the oxidative stress regulator OxyR in Pseudomonas aeruginosa PAO1 impairs growth under iron-limited conditions. FEMS Microbiol. Lett. 288: 258-265.

Vinckx, T., Wei, Q., Matthijs, S., and Cornelis, P. 2010. The Pseudomonas aeruginosa oxidative stress regulator OxyR influences production of pyocyanin and rhamnolipids: Protective role of pyocyanin. Microbiology 156:678-686.

Wang, H., and Joseph, J. A. 1999. Quantifying cellular oxidative stress by dichlorofluorescein assay using microplate reader. Free Radic. Biol. Med. 27:612-616.

Wang, Y., and Newman, D. K. 2008. Redox reactions of phenazine antibiotics with ferric (hydr)oxides and molecular oxygen. Environ. Sci. Technol. 42:2380-2386.

Wojtaszek, P. 1997. Oxidative burst: An early plant response to pathogen infection. Biochem. J. 322:681-692.

Xia, X., Larios-Valencia, J., Liu, Z., Xiang, F., Kan, B., Wang, H., and Zhu, J. 2017. OxyR-activated expression of Dps is important for Vibrio cholerae oxidative stress resistance and pathogenesis. PLoS One 12: e0171201.

Xu, S., Pan, X., Luo, J., Wu, J., Zhou, Z., Liang, X., He, Y., and Zhou, M. 2015. Effects of phenazine-1-carboxylic acid on the biology of the plantpathogenic bacterium Xanthomonas oryzae pv. oryzae. Pestic. Biochem. Physiol. 117:39-46.

Xu, Y., Zhu, X. F., Zhou, M. G., Kuang, J., Zhang, Y., Shang, Y., and Wang, J. X. 2010. Status of streptomycin resistance development in Xanthomonas oryzae pv. oryzae and Xanthomonas oryzae pv. oryzicola in China and their resistance characters. J. Phytopathol. 158:601-608.

Yano, T., Kassovska-Bratinova, S., Teh, J. S., Winkler, J., Sullivan, K., Isaacs, A., Schechter, N. M., and Rubin, H. 2011. Reduction of clofazimine by mycobacterial type $2 \mathrm{NADH}$ :quinone oxidoreductase: A pathway for the generation of bactericidal levels of reactive oxygen species. J. Biol. Chem. 286:10276-10287.

Yu, C., Wang, N., Wu, M., Tian, F., Chen, H., Yang, F., Yuan, X., Yang, C. H., and He, C. 2016. OxyR-regulated catalase CatB promotes the virulence in rice via detoxifying hydrogen peroxide in Xanthomonas oryzae pv. oryzae. BMC Microbiol. 16:269-281. 